\title{
O CONTROLE SOCIOJURÍDICO DA SEXUALIDADE
}

\author{
THE SOCIO-JURIDICAL CONTROL OF SEXUALITY
}

\author{
Pâmela Copetti Ghisleni ${ }^{\mathrm{I}}{ }^{\mathrm{B}}$ \\ Doglas Cesar Lucas ${ }^{\mathrm{II}}$ (i) \\ André Leonardo Copetti Santos ${ }^{\mathrm{III}}$ (i)
}

${ }^{\mathrm{I}}$ Faculdade CNEC Santo Ângelo (CNEC), Santo Ângelo, RS, Brasil. Mestre em Direito.

E-mail: pcghisleni@gmail.com

II Faculdade CNEC Santo Ângelo (CNEC), Santo Ângelo,

RS, Brasil. Universidade

Regional do Noroeste do Estado do Rio Grande do Sul (UNIJUÍ), Ijuí, RS, Brasil.

Pós-Doutor em Direito. E-mail: doglasl@unijui.edu.br

${ }^{\text {III }}$ Universidade Regional Integrada do Alto Uruguai e das Missóes - Santo Ângelo (URI Santo Ângelo), Santo Ângelo,

RS, Brasil. Universidade

Regional do Noroeste do Estado do Rio Grande do Sul (UNIJUÍ), Ijuí, RS, Brasil.

Pós-Doutor em Direito. E-mail: andre.co.petti@hotmail.com
Resumo: As relaçôes interpessoais no mundo contemporâneo impóem uma inversão radical em relação às vivências das sociedades tradicionais. Neste cenário - de novas formas de construção de subjetividades, autenticidades e mesmo de pertença- ganham fôlego as chamadas "práticas eróticas não convencionais". Este texto pretende, a partir do emprego da fenomenologia hermenêutica, trazer reflexões acerca das incoerências das narrativas jurídicas sobre aquelas "experiências-limite", a fim de demonstrar que tais práticas definitivamente colocam em xeque a forma como o Direito pensa, (re)produz e gesta a regulação do sexo e da sexualidade.

Palavras-chave: Controle Social. Direito. Sexualidade. Tolerância. Violação.

Abstract: The interpersonal relations in the world impose a radical inversion in relation to the experiences of the matrices. In this scenario - new forms of construction of subjectivities, authenticity and belonging - gain breath as so-called "unconventional erotic practices". This text intends, from the use of hermeneutic phenomenology, to reflect on the incoherencies of legal narratives about the same limit experiences, in order to show that they are put in check as a form of the law thinks, (re) produce and gestates the regulation of the sex and sexuality.

Keywords: Social Control. Law. Sexuality. Tolerance. Violation.

\section{口itu}

DOI: http://dx.doi.

org/10.31512/rdj.v20i37.24

Recebido em: 14.05.2019

Aceito em: 20.02.2020 


\title{
1 Consideraçóes iniciais
}

\begin{abstract}
O erotismo abre um abismo. Querer iluminar suas profundezas exige ao mesmo tempo uma grande resolução e uma calma lucidez, a consciência de tudo aquilo que uma intenção tão contrária ao sono geral coloca em jogo: é certamente o mais horrivel, e é também é mais sagrado (Georges Bataille).
\end{abstract}

Se as sociedades tradicionais convencionalizaram as relaçóes interpessoais, estabelecendo noçóes existenciais estritamente sedentárias e não raro utilitaristas, o mundo contemporâneo apresenta-se, em toda sua fluidez e efemeridade, como uma ruptura radical em termos de afeto, desejo e sexualidade. Tais categorias, agora reinventadas, ressignificam também as percepção acerca do que seja dor, violência, agressão e, ao fim e ao cabo, prazer. Inobstante, aqueles temas até então afetados pela cena jurídica apenas esporadicamente, começam a demandar um lugar no ordenamento jurídico, o que fazem a partir de um movimento vacilante e paradoxal que, por um lado, reivindica sejam positivadas certas posiçóes jurídicas e, por outro, clama por não interferência.

Prostituição, sadomasoquismo, pornografia (e sobretudo o polêmico pornô bizarro), sex toys e as boutiques eróticas, swing, spanking, voyeurismo, ménage à trois ${ }^{l}$ : na discussão que envolve sujeitos autônomos e capazes, como não cruzar a "linha vermelha" do sexo são, seguro e consensual? Em um mundo que catalisou as individualidades humanas ao extremo, há, de fato, uma "linha vermelha" em comum? E mais - e aqui reside a principal problemática a ser abordada neste estudo - o Direito e seus horizontes epistemológicos são capazes de narrar tais questôes a partir da lógica jurídica tradicional?

Nesse sentido, este texto pretende trazer reflexóes acerca das incoerências das narrativas jurídicas contemporâneas em torno do chamado erotismo não convencional, a fim de demonstrar que as práticas-limite definitivamente colocam em xeque a forma como o Direito pensa, (re)produz e gesta a regulação do sexo e de tudo o que está no seu entorno.

Para desenvolvimento da pesquisa, utilizar-se-á o método da fenomenologia hermenêutica. Far-se-á, portanto, revisão crítico-reflexiva dos temas transmitidos pela tradição filosófica por meio da linguagem (STRECK, 2014), horizonte metodológico mais adequado à discussão da temática objeto deste artigo.

Deixar e fazer ver a apropriação do sexo e da sexualidade pelo discurso jurídico por si mesma, tal como se mostra a partir de si própria, requer uma metodologia que permita

1 A infinitude de práticas eróticas não convencionais impossibilita que tais temas sejam trabalhados de forma melindrosamente categorizada. Por isso, todas estas abordagens serão aqui denominadas sob a alcunha de erotismo não convencional, subversivo ou transgressor. Ainda, não se pode deixar de incluir nesse rol a sexualidade que foge do padráo heteronormativo, a exemplo daquela dos gays, lésbicas e bissexuais, pois muito embora o mundo contemporâneo já esteja, em certa medida, mais habituado à discussão, ainda são muitos os entraves que a população LGBTI tem enfrentado. 
tal aproximação ao fenômeno, de modo que seja possível a ele demonstrar-se diretamente e não a partir de postulados de outros fenômenos ou doutrinas tradicionais. A proposta de trabalho busca não a abordagem dessa apropriação discursiva em particular, mas aspectos do seu ser, os quais embora se mostrem de forma implícita e "não-tematizada", podem chegar a mostrar-se tematicamente. Para tal desiderato, o método fenomenológico fazse não somente adequado, mas fundamentalmente necessário, especialmente porque o elemento principal de análise a ser abordado - o assenhoramento do desejo pelo Direito - está velado tanto pela sua proximidade e familiaridade em nosso cotidiano (o que faz com que nem notemos e nos pré-ocupemos com tal aspecto) quanto pelo fato de ele estar enterrado sob conceitos e doutrinas hauridas a partir de um pensar calculador jurídico que impede uma reflexão meditativa a respeito dos limites do poder do Direito estatal em relaçáo a este campo fenomênico. Assim, a partir da fenomenologia hermenêutica, buscar-se-á construir o significado da (i)legitimação democrática dessa apropriação normativa do sexo e da sexualidade, cuja interpretação está obscurecida pelos pré-conceitos de interpretaçóes passadas assentadas sobre doutrinas dogmáticas tradicionais. Trata-se, por esta perspectiva metodológica, de tentar alcançar o maior grau possível de reflexividade sobre o "lugar" desde onde se enuncia esse discurso apropriativo. Uma pequena reconstrução histórica é parte da estratégia argumentativa. Trata-se de uma destruição ontológica (Heidegger), de uma des-construção discursiva (Derrida), de uma re-construção epistemológica (Habermas) desde os vencidos, desde as vítimas, principalmente de um Direito da Modernidade que sempre teve a pretensão de racionalidade, mas em termos de sexo, desejo, sexualidade, sempre foi corroído por préconceitos absolutamente irracionais.

\section{Calar, controlar, transgredir: sexo e sexualidade entre a cruz e a espada}

Modos de vestir, de comer, de dormir, de existir. Para todas as minúsculas trivialidades da vida são construídas racionalizaçóes de relevante complexidade simbólica. Não se pode negar, no entanto, que as ponderações relativas aos "modos sexuais" são, não raras vezes, ainda mais labirínticas e difíceis de administrar. Mas por que estabelecemos para a sexualidade humana normas morais que parecem receber (e efetivamente recebem) tanta atenção? (FOUCAULT, 2012). De que estruturas (in)conscientes e elaboraçóes culturais estamos falando quando pensamos nos modos de amar e desejar que nós, enquanto espécie humana, inventamos? Questionamentos dessa ordem traduzem a inquietação dos muitos autores que a partir do século XX se debruçaram na difícil empreitada de (tentar) descortinar o poder no contexto da sexualidade humana. Com efeito, muito mais do que um comportamento (também) animal, a atividade sexual humana tornou-se um ato simbólico que envolve questóes outras, tendo cada vez menos vinculação com o esforço meramente reprodutivo, o que significa dizer que "apenas os homens fizeram de sua 
atividade sexual uma atividade erótica, ou seja, uma busca psicológica independente do fim natural dado na reprodução e no cuidado com os filhos" (BATAILLE, 2014, p. 35).

Nos povos caçadores-coletores havia uma grande preocupação em torno da escassez de alimentos, daí a necessidade de impor severos limites ao número de filhos. Apesar das restrições a aspectos cruciais da sexualidade em razáo da escassez econômica, os povos caçadores-coletores performavam uma enorme variedade de práticas sexuais. No entanto, não se pode negar que a condiçáo biológica da mulher acabava, invariavelmente, encarregando-a do cuidado com a prole, destinando-lhe uma existência sedentária. $\mathrm{O}$ homem, por outro lado, na medida em que se arriscava na atividade da caça, da pesca e da guerra, concentrou o poder simbólico em suas mãos (BEAUVOIR, 2009).

Este cenário muda substancialmente com o surgimento da agricultura, entre 9000 e 5000 a.C., havendo, a partir de então, uma noção mais clara de estabilidade e permanência, facilitando-se a supervisão coletiva do comportamento sexual. A detenção da propriedade fez com que fosse necessário, mais do que nunca, estabelecer a paternidade de modo preciso, o que permitiu o desenvolvimento de novas regras de controle da sexualidade feminina (STEARNS, 2010).

Entre 2.500 e 500 a.C. surgiram grandes civilizaçóes clássicas no Oriente Médio, no Mediterrâneo, na China e na Índia, nas quais estão enraizados os primeiros sistemas políticos e legais, iniciando-se de maneira escrita a esfera pública (DUSSEL, 2007, p. 20 e segs). Não obstante as pequenas variaçóes, é possível verificar uma linearidade no sentido de que basicamente todas elas estabeleceram marcadores sociais da diferença entre os sexos. Os gregos - cujas práticas repercutem de modo especial no mundo Ocidental empenharam-se para regular a sexualidade feminina, sobretudo por meio da virgindade. Os casamentos eram estabelecidos com base em arranjos econômicos e, de maneira geral, havia uma grande ênfase na monogamia, o que, não se pode negar, soa ainda familiar aos modos contemporâneos de estabelecer relações.

As mulheres eram vistas com desprezo pelos homens, pois libertinas e imorais por natureza. Além disso, havia o entendimento de que se relacionar com uma mulher era uma questáo ordenada pela natureza para a conservação da espécie, desdenhado justamente em virtude da associação com o deleite sexual. $\mathrm{O}$ único amor verdadeiro, então, era o dos rapazes. De fato, "a mulher grega é reduzida a uma semiescravidão; ela não tem sequer a liberdade de se indignar." (BEAUVOIR, 2009, p. 132).

$\mathrm{O}$ envolvimento entre pessoas do mesmo sexo, notadamente entre homens, era lugar comum na Grécia Antiga. "A homossexualidade na Grécia relacionava-se estreitamente com a masculinidade, e é importante captar esta perspectiva de modo a entender seu papel social." (RICHARDS, 1993, p. 138). Em linhas gerais, essa conduta com relação à homossexualidade ${ }^{2}$ e ao erotismo na Grécia resultou em um problema de

2 Importa esclarecer que termos como heterossexualidade, homossexualidade, homoafetividade ou homoerotismo, 
difícil solução para as sociedades posteriores que encontraram muitas de suas referências na civilização grega, mas reprovavam ou omitiam alguns dos seus aspectos clássicos.

A sociedade romana, por sua vez, manteve ou copiou diversos temas gregos, mas tinha uma opiniáo ligeiramente mais elevada sobre as mulheres, as quais eram menos sujeitas ao controle na esfera pública. Apesar de certa desaprovação pública, a "homossexualidade" - vista como sintoma da depravaçáo grega - existiu também em Roma.

A despeito, portanto, de algumas supostas liberdades, nas sociedades clássicas também existia uma tendência de limitar o sexo. Essa predisposição tornou-se ainda mais saliente com o impacto da religiáo. Em se tratando de sexualidade, a religiấo foi a maior das novas influências na história mundial. É que, ao contrário das religiôes primitivas, que muitas vezes concebiam a sexualidade em termos de uma relação positiva e transcendental com a espiritualidade, as novas crenças invariavelmente buscaram minimizá-la ou regulála (STEARNS, 2010).

Nesse sentido, a influência cristã desenvolveu uma desconfiança fundamental em relação à sexualidade. Com efeito, a versão do catolicismo que se difundiu pelo mundo ocidental(izado) era mais desconfiada e receosa do que as outras ramificaçóes cristâs. Desde o princípio, portanto, o cristianismo procurou estabelecer uma cisão fundamental, consubstanciada no fato de que Jesus nasceu de uma virgem, e não como resultado do coito. Para tanto, disseminou-se a noção de um Deus transcendental e que, consequentemente, está em todos os lugares e ao mesmo tempo em lugar nenhum.

A influência judaica também colaborou para uma visão restritiva do sexo, o qual devia ser confinado ao casamento e priorizar a reprodução, já que a prática em demasia era um erro espiritual, ainda que no âmbito do matrimônio. Era essa mesma compreensão que fortalecia, especialmente no século XIV, a percepção católica acerca da homossexualidade. É que diante das pestes que dizimaram boa parte da população europeia, procriar tornou-se uma necessidade urgente (RICHARDS, 1993).

A influência grega acerca da condição feminina foi fundamental para enfatizar a fraqueza moral de tudo o que estivesse relacionado ao mundo feminino. A ideia de Eva como a primeira pecadora e a crença generalizada de que as mulheres eram seres inferiores aos homens contribuíram para justificar penalidades mais severas para mulheres naquilo que dizia respeito ao corpo, como o estupro e o adultério. Era (e ainda é) corriqueiro a sociedade dividir as mulheres em respeitáveis e não respeitáveis ${ }^{3}$. Nessa perspectiva,

em que pese possam ser utilizadas neste texto no contexto das civilizaçóes antigas, eram desconhecidos na época, tendo sido elaborados a partir da concepção de envolvimento erótico e afetivo somente no mundo moderno. A própria expressão "sexualidade" apenas é utilizada a partir do século XIX. Essa observaçáo é fundamental porque possibilita uma análise que facilita a comunicação mas evita a transposição equivocada de conceitos do imaginário contemporâneo para a Antiguidade.

3 Havia no Código Penal brasileiro (Decreto-Lei no 2.848/1940) uma série de dispositivos incriminadores, no Título VI da Parte Especial, denominado de "Crimes contra os Costumes", com vigência até o ano de 2009, 
os corpos, especialmente os femininos e grávidos, eram perpassados por angústias que ditavam a dinâmica da sociedade e da civilizaçáo medieval.

Entre 1450 e 1750 o mundo foi palco de uma intensificação do comércio global e do desenvolvimento de um poder colonial e marítimo. As maiores mudanças e complexidades relacionadas à sexualidade no período diziam respeito aos encontros entre povos. A dominação europeia e as novas formas de escravidão, portanto, tiveram consequências elementares para a sexualidade. Doenças até então desconhecidas dizimaram populaçóes americanas, criando a oportunidade para que alguns grupos de europeus assumissem posições de poder no Novo Mundo.

As mudanças mais significativas envolvendo a sexualidade humana começaram a surgir apenas entre os séculos XVIII e XIX, dando formato ao que pode ser chamado de Primeira Revolução Sexual. Boa parte deste processo deveu-se à tendência, agora mais clara, de separação do sexo da procriação, o que sinalizava para o fato de que era possível usufruir da sexualidade apenas para obter prazer (STEARNS, 2010).

Essa primeira revolução foi, de fato, mais discreta e, apesar disso, a reação social dos setores que objetivavam defender os padróes tradicionais foi bastante severa. $\mathrm{O}$ resultado foi um novo movimento que incorporava um moralismo sexual na cultura, nas leis e nos comportamentos: o vitorianismo.

O mais duro golpe sofrido pelo vitorianismo foi desencadeado pelas campanhas destinadas a ampliar o acesso a dispositivos contraceptivos. Lançada em 1960, nos Estados Unidos, a pílula Enovid-10 permitiu que as pessoas vivessem sua sexualidade de forma mais livre, libertando notoriamente as mulheres que, antes enclausuradas no risco iminente da gravidez, a partir de então podem escolher seu parceiro, trair e gozar seu desejo, ainda que de forma significativamente velada. Foi também nesse período que algumas feministas começaram a abordar a temática do interesse e do prazer sexual, transcendendo os tradicionais temas da violência e da gravidez indesejada. Evidenciava-se aí a definitiva dissociação entre sexualidade e reprodução.

Com Sigmund Freud (1856-1939) e o surgimento da psicanálise, lançaram-se as luzes sobre uma série de percepçóes outras a respeito dos sujeitos e dos corpos que tinham estado adormecidas. Em contraposição ao racionalismo do século XVIII que apartou

quando foram então revogados pela Lei no 12.015, de 07 de agosto de 2009. Tais preceitos utilizavam como elemento normativo do tipo penal a expressão "mulher honesta" na descrição de determinados modelos abstratos de condutas puníveis. Assim, o crime de "posse sexual mediante fraude", previsto no art. 215, como "ter conjunção carnal com mulher honesta, mediante fraude, punido com pena de reclusão de um a três anos; ou o «atentado ao pudor mediante fraude", descrito no art. 216 como «induzir mulher honesta, mediante fraude, a praticar ou permitir que com ela se pratique ato libidinoso diverso da conjunção carnal», e punido com pena de reclusão de um a dois anos; ou, por fim, o «rapto violento ou mediante fraude", positivado no art. 219 como "raptar mulher honesta, mediante violência, grave ameaça ou fraude, para fim libidinoso", castigado com pena de reclusão de dois a quatro anos. Ou seja, até o ano de 2009, tínhamos alguns crimes que somente podiam ser praticados contra mulheres de primeira classe, de ilibada e idônea reputaçáo, mas jamais contra alguma classe de mulheres - "desonestas" - que ninguém sabia exatamente quem poderiam ser, a não ser o juiz da causa. 
corpo e razão, o austríaco introduziu novamente o ser em sua materialidade corpórea. $\mathrm{O}$ pai da psicanálise escancarou o fato de que os traços sexuais associados à perversão são, em verdade, comuns a toda gente. Com isso, restaurou e aprofundou a temática da carne, da carcaça, do corpo orgânico e biológico, potencializando a discussão em torno daquilo que o corpo tem de mais íntimo, profano e interdito: a sexualidade (FREUD, 2016).

No entanto, nada do que existia por volta de 1950 pronunciava de forma plena a (re)definição da sexualidade que ocorreria nos sessenta anos seguintes. No período posterior às décadas de 1950 e 1960, criou-se uma opinião mundial mais tolerante do ponto de vista da sexualidade, apesar das exageradas reaçóes locais às propostas contemporâneas. Três fatores estão particularmente envolvidos nessa revolução sexual. Começa a ganhar corpo, a partir de 1950-60, uma nova cultura sexual caracterizada por ser mais aberta. Surgem novos tipos de controle de natalidade e um empenho cada vez maior na busca do prazer por meio do sexo recreativo. Um segundo fator está relacionado à globalização, ao consumismo e à possibilidade do turismo internacional proporcionado pelas novas empresas transnacionais. Por fim, o terceiro elemento diz respeito às diversas reaçóes regionais e inovaçóes que os defensores dos padróes mais tradicionais julgavam fundamentais como forma de proteção contra uma cultura sexualmente aberta (STEARNS, 2010).

O capitalismo foi particularmente decisivo para os relacionamentos interpessoais. Essa nova dinâmica fez com que homens e mulheres se vissem obrigados a viver como indivíduos autodeterminados, gestores da própria vida. Se havia a possibilidade de escolher um trabalho e, graças à remuneração, existia a perspectiva de uma independência material, por que os sujeitos não poderiam fazer o mesmo com relação à sua vida privada, escolhendo também seus parceiros ou parceiras? (FERRY, 2008). Nesse sentido, a partir de 1960, a família contemporânea funciona sob a lógica do par, ou seja, dois indivíduos que se unem em busca de relaçóes íntimas ou realização sexual. Aqui, vale a comunidade a dois a que se referem Beck e Beck-Gernsheim (1998).

Nessa perspectiva, a internet modificou substancialmente os relacionamentos amorosos ao mercantilizar e textualizar os afetos (ILLOUZ, 2011). Para Miskolci (2017, p. 43), esse é um fato posto e incontestável e, partindo dessa premissa, o sociólogo afirma que "vivemos em uma sociedade em que as relaçóes interpessoais foram crescentemente moldadas pelos conteúdos da indústria cultural e mediadas pelas telecomunicaçóes."

É também do início do século XXI a popularização do Viagra para a disfunção erétil. Os medicamentos deste tipo privilegiaram quase que invariavelmente o público masculino, o que em muito se deve ao estereótipo de gênero calcado na performance de masculinidade .

4 Entretanto, o aumento expressivo do interesse feminino no prazer sexual e a cobrança masculina pela maior disponibilidade e disposição das mulheres fomentaram novas pesquisas que permitiram a confecção da flibanserina, o "Viagra feminino". 
Outro ponto a ser abordado diz respeito à elevação da idade vista como adequada para o casamento. É que a necessidade de instrução formal passou a manter os jovens mais tempo na escola, na graduação e, mais recentemente, na pós-graduação. Desse modo, demoram cada vez mais para galgar uma estabilidade financeira que permita o casamento, nos casos em que ainda é desejado. Essa situação criou as condições adequadas para o fomento do sexo pré-marital, justificando-o.

No entanto, a notícia mais impactante no terreno da sexualidade nos últimos anos foi, sem dúvida, a Síndrome da Imunodeficiência Adquirida - AIDS. A doença foi identificada pela primeira vez por volta de 1980, quando o paciente morria após um período de devastadora debilitação e sintomas muito dolorosos e visíveis. De maneira geral, a AIDS foi associada à homossexualidade e ao uso de drogas e, portanto, a uma vida desregrada ou pelo menos que não respondia aos padróes comportamentais e culturais da época. Nessa senda, ganham novo alento as campanhas em nome da abstinência sexual total.

A homossexualidade foi um dos últimos campos no qual as tendências globais emergiam de modo complexo e hesitante. Era preciso redefinir a homossexualidade como uma orientação sexual permanente, e não como um comportamento ocasional e calcado apenas em impulsos sexuais. Um importante progresso reside no fato de que a justificativa biológica da heterossexualidade como sendo o normal é pouco a pouco questionada (quando não desmantelada) nas sociedades modernas (GIDDENS, 1993).

Um forte movimento dos direitos dos homossexuais começou a ganhar fôlego nos Estados Unidos na década de 1960. Em 1973, a Associação Norte-Americana da Psicologia removeu as referências à homossexualidade como uma doença. Se por um lado, a AIDS criou novas hostilidades com relação aos homossexuais, por outro, ela tornou possível que outros grupos sexualmente vulneráveis como bissexuais e transgêneros começassem a expressar sua orientação sexual e suas preocupações sobre a aceitação da sua condição.

Em termos teóricos, os feminismos trouxeram grandes avanços e novas complexidades para o mundo da sexualidade. Mas uma importante transformação, se não a mais importante, foi desencadeada pela política pós-identitária, influenciada pelo pósestruturalismo e pelo desconstrutivismo francês. Com efeito, essa teoria foi retomada pelo mundo acadêmico, sobretudo nas notáveis análises feministas que usaram a abordagem desconstrucionista e a estratégia da diferência (différance) para originar novos termos que ignoram os dualismos em geral, mas, mais incisivamente, o dualismo entre o feminino e o masculino.

Por volta de 1990, Judith Butler (2016) inseriu-se com a teoria queer em um debate que, embora já viesse sendo problematizado pelo feminismo, jamais havia sido escancarado e radicalizado da forma como esta filósofa procedeu. Butler (2016) repensou a mulher como sujeito protagonista do feminismo, rejeitando todo o essencialismo 
ou definição naturalizante de feminilidade. É possível estabelecer políticas, diz Butler (2016), sem que seja necessária uma identidade fixa, pré-moldada e, portanto, castrada, que inclui invariavelmente excluindo.

Do exposto, é possível afirmar que a maior parte das sociedades está vivendo uma grande transformação no que diz respeito à sexualidade, consistente na passagem de sistemas profundamente arraigados e derivados de sociedades agrícolas a uma situação ainda não tão bem definida ou mapeada, que é moldada pela necessidade (e pelo desejo) de reproduzir e por um novo tipo de cultura de consumo. Além disso, a rapidez com que tais transformaçóes vêm ocorrendo faz com que muitas pessoas se defrontem com padróes comportamentais e sexuais para os quais náo foram criadas ou educadas. Nessa senda, desafios ainda maiores são agregados à sexualidade e às ciências que se propóem a discursar em torno dela e dos novos pactos que ela tem estabelecido.

\section{Narrando o inenarrável: o Direito tem algo a dizer sobre o sexo?}

A aproximaçáo entre o Direito e a sexualidade evoluiu sempre no sentido de obedecer a uma lógica normativa patriarcal, de modo que não são poucos os que têm sido vítimas históricas de um sistema de dominação calcado na lógica binária dos gêneros e na matriz heterossexual da lei, simplesmente porque desejam, gozam, amam e se satisfazem de forma distinta daquela estabelecida pelo padrão heteronormativo (BORRILLO, 2010). Com efeito, estabeleceu-se a binariedade heterossexual como sinônimo de normalidade, ao passo em que qualquer outra possível manifestação da sexualidade recebeu o rótulo de anormal a que se refere Foucault (2014a). Ou seja, o discurso que se naturaliza narra um ser inteligível somente na medida em que adquire um gênero que, por sua vez, deve ser ele também inteligível (BUTLER, 2016), consubstanciado naquela coerência e continuidade entre sexo, gênero, prática sexual e desejo.

Antes mesmo do nascimento, a criança (o humano em devir) é inscrita em uma ou outra classe sexual. Não há ser humano. Aquele sujeito que sequer nasceu é (será) menino ou menina. Essa designação prévia é responsável por determinar uma série de consequências para o self, porque nessa ordem binária dos sexos (macho ou fêmea) há uma expectativa muito clara acerca dos comportamentos esperados para cada um deles, quase como se dita atribuição colonizasse e conformasse o indivíduo. Isso deriva, em boa medida, dos protótipos de masculinidade e feminilidade. Além de se tratar de uma lógica binária - já que se limita sempre a dois termos, sendo que ao assumir-se um exclui-se o outro (homem ou mulher, heterossexual ou homossexual) - há também a circunstância atributiva, no sentido de que a cada um desses polos são acomodadas determinadas características, geralmente complementares e opostas, as quais fixam o "um" ou o "outro" do par numa posição hierárquica. Essa hierarquização, entretanto, não se limita ao campo 
da sexualidade (embora nela constantemente desague), abarcando categorias outras como raça, classe social e etnia.

Mas a verdade é que se o feminismo visibilizou a metade oculta da humanidade, o Outro a que se refere Beauvoir (2009) também não tem deixado de pensar a humanidade em termos binários, pressupondo a existência de dois gêneros estáveis. O Direito é denunciado pelo feminismo tradicional como sendo um instituto masculinizado, de modo que para democratizá-lo bastaria (também) feminilizá-lo. Essa abordagem, contudo, é insuficiente, pois vem amparada em uma perspectiva segundo a qual o acesso à igualdade deve se realizar levando em consideração a especificidade de um ou outro sexo.

Nenhuma sociedade conseguiu, até hoje, escapar do imperativo de socializar a diferença entre masculino e feminino. Embora os conteúdos no que diz respeito aos processos de diferenciação e segregação dos sexos variem de uma cultura para a outra, o processo em si é universal. Há, nessa perspectiva, algo que Borrillo (2010) chama de uma identificação subjetiva e uma complementaridade objetiva. Em resumo, o comportamento esperado do sujeito nascido na condição de fêmea traduz-se na fragilidade que, a seu turno, concorda com a firmeza que supostamente conforma o sujeito nascido macho. Essa relação de complementaridade se adequa perfeitamente ao ideal do casamento, instituição na qual se interpretam os papéis de gênero atribuídos socialmente, endossando, além da lógica binária dos gêneros, a matriz heterossexual da lei.

Tudo isso porque o Direito ainda se sustenta na racionalidade reprodutiva, embora essa concepção esteja, pouco a pouco, assumindo novas formas. $\mathrm{O}$ matrimônio, portanto, emerge como o único lugar legítimo para o exercício da sexualidade. Assim percebido, o Direito existe nos termos da lógica foucaultiana (2010) segundo a qual um poder que age somente reprimindo, censurando, excluindo, impedindo, ou seja, negativamente, tornase, paulatinamente, muito frágil. De fato, o que se vê hoje é um poder que produz efeitos positivos no desejo e no saber, arquitetando o saber que lhe convém, encrustando-se no discurso, motivo pelo qual é difícil desprender-se dele. Desse modo, o Direito aparece não somente como um depósito do real, mas como o criador da realidade (FOUCAULT, 2010).

A sexualização do sujeito pelo Direito continua a ser um ato de produção de desigualdades ocultas pelo caráter natural da atribuição dos gêneros, tanto pelo estabelecimento do estado das pessoas, como também pelo acesso ao direito ao casamento e à filiaçáo (BORILLO, 2010). No que diz respeito ao estado das pessoas, embora existam raras exceçôes, quando o sujeito é catalogado pelo Direito ele assume necessariamente a condição de macho ou fêmea. Não parece existir solução que fuja da dualidade dos sexos ${ }^{5}$. $\mathrm{Na}$ perspectiva do direito ao casamento e à filiaçáo, o titular do direito ao matrimônio

5 Nessa perspectiva, a transexualidade evidencia a complexidade do sexo e dos diversos componentes que estão no seu entorno (BORRILLO, 2010). 
é identificado pelo gênero, como se a diferença entre os sexos fosse uma condição para a uniáo. É que os conceitos de homem (marido) e mulher (esposa) reverberam a noção sexual de pai e de mãe, de modo que o casamento se constitui no espaço institucional ideal da diferença entre os sexos. Illouz (2011) adverte que grande parte do desgosto e da decepção que o matrimônio causa na modernidade tem relação com o fato de que essa instituição estrutura as relaçóes de gênero e combina uma lógica emocional (do eu) com uma lógica social (do todo). O casamento, nesse sentido, ilustra perfeitamente a distância entre o meu desejo (de igualdade de gênero) e a inevitabilidade sobre os papéis de gênero.

É dizer, o Direito impõe uma visão normalizadora da sexualidade. Ao contrário da moral religiosa que impóe um sentido unívoco da sexualidade, o Direito dos Estados laicos deve abster-se dessa tentativa (e é sempre só uma tentativa), movimento que obviamente tende ao fracasso em função dos acoplamentos estruturais entre os sistemas religioso e jurídico, situação que, não raro, tem permitido a normatização estatal de fundamentalismos religiosos. Renunciar a um modelo erótico uniforme implica constatar a pluralidade sexual e a equivalência de todas manifestaçóes, de modo a abraçar todas as sexualidades. Em resumo, nenhuma sexualidade em particular deve ser promovida ou incentivada em detrimento de outras manifestaçóes livremente consentidas, ou seja, emanadas de pessoas capazes e sem vícios de consentimento (BORRILLO, 2015).

No labirinto de possibilidades que a sexualidade humana oferece, existem aqueles que encontram nela uma fonte de prazer, outros que a renunciam (seja por respeito a preceitos religiosos, seja por ausência de interesse erótico/sexual). Outros, ainda, a convertem em uma atividade comercial e há quem a vivencie do ponto de vista de uma obrigação moral oriunda das relaçóes amorosas. $\mathrm{O}$ desejo, nesses casos, pode assumir as mais diversas formas, tudo isso para dizer que "existem tantas sexualidades quanto os sujeitos que as praticam." (BORRILLO, 2015, p. 04).

Por conseguinte, percebe-se que historicamente foram estabelecidos (e impostos) modelos de verdade que sufocaram e castraram as possibilidades que a vida e os corpos oferecem. Qualquer expressão ou manifestação sexual, estética ou de identidade gênero que se assemelhasse a essas possibilidades sufocadas e castradas, passa pelo reconhecimento através da classificação, do diagnóstico, da patologização, da perversão, da loucura, do crime, da exclusão e da morte. Nesse sentido, é "vital” para a construção de uma percepção "normal" da sexualidade - centrada na heterossexualidade e na procriaçáo - enquadrar o "desviante" sob o rótulo de perverso (STOLLER, 2015). Dito de outro modo, a perversão como fenômeno sexual, político, social, psíquico, trans-histórico e estrutural está presente em todas as sociedades humanas. E não são os fatos e as sexualidades em si os problemas ou anomalias, mas o discurso construído para eles em um determinado tempo e lugar (ROUDINESCO, 2008). 
No que diz respeito à sexualidade, especificamente, sua regulação jurídica está sendo cada vez mais relacionada à esfera penal. Não há, todavia, como louvar a iniciativa de se utilizar a penalização para impor pautas morais de comportamento no que se refere às práticas sexuais, tendo em vista que essa dimensão da vida está circundada, talvez mais do que qualquer outra, por convicções íntimas e pela consciência individual (CORREA, 2006).

Outrossim, é importante que o debate relativo à sexualidade na cena jurídica abarque além da condição feminina, pois enquanto as mulheres assumem (ainda que desigualmente) um lugar no interior do contrato social - e por isso a legislação a elas atinente está no código civil, em sua maioria -, os outros sujeitos sexuais que demandam proteção estáo posicionados fora do contrato, excluídos. Ou seja, esses outros sujeitos sexuais - homossexuais, profissionais do sexo, transexuais, sadomasoquistas, etc. - são pensados a partir de leis penais ${ }^{6}$ (CORRÊEA, 2006).

Com a "morte" de Deus, da religião e da crença em valores metafísicos (NIETZSCHE, 2012), os juristas precisaram lançar máo de um novo arcabouço que proporcionasse uma sensação existencial de segurança, agora perdida. Mesmo diante de um mundo no qual imperava a pluralidade, a diversidade e a desigualdade - visibilizandose cada vez mais as concepçóes alternativas de dignidade humana - esse seleto grupo esforçou-se para ocultar a complexidade do mundo, pelo menos no universo normativo. Há, por consequência, uma perda de todo o arcabouço sociológico de determinadas causas quando o Direito se apropria de conceitos como violência de gênero, liberdade sexual, violência doméstica etc. Essa simplificação, a partir da igualdade, dificulta a tarefa do Direito de penetrar as camadas mais profundas da realidade, de modo a "traduzir a complexidade para o seu universo instrumental destinado à solução de conflitos multifacetados, como os que surgem diariamente, especialmente no campo da sexualidade" (SANTOS; LUCAS, 2015, p. 126).

Nesse prisma, o edifício jurídico reduz a complexidade do mundo da vida, e a revolução tecnológica foi fundamental para que a diversidade acobertada sob o manto da igualdade viesse à tona. A igualdade, tal qual foi formulada pelos contratualistas/ liberais/iluministas dos séculos XVI a XVIII, surge, então, não mais como um ideal a ser buscado, mas como coação, castração e aprisionamento do ser. "O capitalismo, para acomodar os indivíduos em seu proveito, impóe modelos de desejo. Assim circulam

6 Por isso não surpreende, embora seja frustrante, que a proteçáo das minorias LGBTI no que se refere à homotransfobia esteja sendo discutida no Supremo Tribunal Federal nos autos da Açáo Direta de Inconstitucionalidade por Omissão (ADO) no 26 e do Mandado de Injunção (MI) no 4.733 essencialmente a partir da lógica sempre perversa da criminalização. É evidente que esses corpos brutalizados, assassinados e relegados ao inexistente merecem um lugar e, talvez sobretudo, a não interferência estatal relativamente à forma como amam e gozam. Nesse sentido, a discussão, ao menos simbolicamente (espera-se que não somente simbolicamente, mas também efetivamente), é de todo fecunda, mas não se pode deixar de dar razão à Sônia Corrêa (2006) no sentido de que o afeto e a sexualidade transcendem, e muito, a dimensão penal. 
modelos de infância, de pai, de casamento, todos construídos em nome do dever e da verdade" (WARAT, 2000, p. 38). Em nome, portanto, da segurança imóvel e sedentária que era proporcionada por aquele Deus, agora morto (NIETZSCHE, 2012).

O Direito moderno, em seu intento de tudo regular e tudo dizer, buscou reduzir a complexidade do mundo da vida, num movimento que se coloca em sentido contrário a dinâmica do real. Enquanto outras áreas do conhecimento humano cultivaram uma conexão especial com o mundo da vida, com o mundo palpável, a ciência jurídica, em vários momentos e em relação a inúmeros temas altamente relevantes para a reprodução da vida, distanciou-se da realidade, sempre objetivando a perfeição, a ordem, a estabilidade ou, no mínimo, a ocultação da concreticidade. É por isso que a ideia de igualdade (pode) representa(r) uma ordenação do real recheada de elementos castradores e totalizantes que mais apartam do que unem. Trata-se de uma forma de intervenção empírica que "impede a manifestação da diversidade dos múltiplos desejos de viver" (SANTOS; LUCAS, 2015, p. 127). A igualdade, da forma como foi estabelecida e ainda hoje é reproduzida, cumpre somente com o objetivo cruel de ocultar o caos, a desordem e a diversidade, traços que traduzem justamente a luminescência de cada experiência humana, que é táo única e justamente por isso, táo rica. A igualdade, naqueles termos, toma a diferença como um atributo negativo, reduzindo-a a formas menores, quando na verdade nossa identidade é tragada pela diferença (DELEUZE, 1988), de modo que existir basta para estar na condição de diferente.

Se o Direito moderno se caracterizou por um elogio à universalidade e à ideia de igualdade formal e abstrata, a partir da década de 1960 inicia-se um movimento épico de visibilização de outras expressóes sexuais e de gênero e, com ele, um erotismo contemporâneo cujos pactos são permeados por uma série de inquietaçóes. Agora, formulam-se outras perguntas que possibilitam a abertura de novos campos de problematizaçáo dentro do universo da sexualidade que até então era (ou deveria ser) absolutamente inteligível. O sujeito antes categorizado como anormal, ininteligível ou perverso, agora demanda um lugar no mundo e na cena jurídica, o que faz a partir de um movimento curioso e paradoxal no sentido de que, por um lado, reivindica sejam positivadas certas posições jurídicas e, por outro, clama por não interferência.

Pouco a pouco, portanto, essa linearidade entre sexo, gênero, desejo e conduta sexual começa a ser questionada, dando ensejo às aqui denominadas práticas eróticas não convencionais, transgressoras ou subversivas. Vê-se, portanto, a emergência política de novas sexualidades que se colocam cada vez mais na condição de merecedoras de reconhecimento, reivindicando espaços de significação e de construção de subjetividades. O que se verifica no mundo contemporâneo é um choque de (e entre as) diferenças, isto é, de especificidades, cada qual postulando não somente reconhecimento jurídico, mas também um reconhecimento que parte do Outro (SANTOS; LUCAS, 2015). 
É chegada a hora de adequar o Direito enquanto institucionalização ao caos e ao movimento do mundo da vida. As lutas que emanam do social devem ser antecedentes a partir dos quais o Direito se (re)constrói. A institucionalização normativa deve, portanto, na medida do possível, funcionar não atrelada a identidades estagnadas. E, ainda assim, se precisar fazê-lo, deve substancializar sempre a forma de ordenação do real, e não o contrário (SANTOS; LUCAS, 2015).

É bom lembrar que no contexto latino-americano o empreendimento de direitos sexuais se desenvolveu num ambiente fortemente marcado pela lei escrita, positivada e, portanto, de tradição romana, ao contrário do que ocorre na tradição anglo-saxônica da common law, cujo cerne são os princípios gerais do contrato social e os procedimentos de jurisprudência, família jurídica no qual surgiram os conceitos de direitos sexuais e reprodutivos. Sônia Corrêa (2006, p. 109) chama esse fenômeno típico das sociedades latinas de sacralização da lei, na medida em que

não pensamos a lei e o direito como uma espinha dorsal do contrato social que pode e deve se transformar à medida que se transformam os sujeitos que os produzem (e suas relaçôes). Mas sim como um arcabouço quase mítico (platônico, poderíamos dizer) que "determina a realidade".

Com efeito, uma regulação justa da sexualidade deve pôr entre parênteses os diferentes significados e conteúdos que cada um imprime à sua vida erótica que, entre adultos e sem vícios de consentimento - e essa observação é fundamental -, possui plena legitimidade. Dessa maneira, a ausência de danos a terceiros e o consentimento manifestado livremente constituiriam os únicos elementos de apreciação jurídica. Todo o resto é simplesmente irrelevante (BORRILLO, 2015).

De fato, boa parte dos instrumentos normativos destinados à tutela da sexualidade foram elaborados com base em percepções sedentárias das identidades ${ }^{7}$. É possível supor, entáo, que a proteçáo dos pormenores da sexualidade (e, repita-se, somente quando for estritamente necessária) não deve estabelecer uma vinculação engessada a identidades ou práticas sexuais, opiniāo de Rios (2007) que é compartilhada por Gregori (2016) e por Borrillo (2010). Uma teoria crítica da sexualidade demanda, primeiramente, que se desconstrua a natureza sexuada do sujeito de direito. Somente assim será possível romper com a ideia de heterossexualidade compulsória, com a biologização da filiação e com a contratualização sedentária dos vínculos familiares.

Uma teoria crítica da sexualidade aplicada ao Direito deve partir justamente das experiências que estão no limite, na margem da norma sócio-sexual (gays, lésbicas, intersexuais, travestis, transexuais, sadomasoquistas, prostitutas, voyeuristas, trisais, etc.) para criticar os dispositivos normativos (casamento, estado civil, filiação) que sempre

7 Do que é um exemplo a recente afirmaçáo da Ministra Damares Alves, nomeada pelo atual Presidente Jair Bolsonaro para assumir o Ministério da Mulher, Família e Direitos Humanos, de que "menino veste azul e menina veste rosa" (QUINALHA, 2019). 
negaram o exercício da cidadania para determinados grupos. Isso quer dizer que a única forma de abraçar todas as subjetividades na norma jurídica é justamente fazendo um movimento em sentido contrário: dessubjetivar a lei, trabalhando com categorias indiferentes relativamente ao sentido que cada sujeito atribuí ao seu gênero, identidade ou escolhas sexuais (BORRILLO, 2015).

Em outras palavras, "o direito da sexualidade não pode se esgotar na proteção identitária, seja de que grupo for" (RIOS, 2007, p. 22), o que significa tecer um direito da sexualidade que fuja dos rótulos e das práticas sexuais predefinidas. É que, ao fim e ao cabo, classificações sectárias, rígidas, fundadas em distinções sexuais, reforçam o machismo e a heteronormatividade compulsória no Direito vigente, impactando negativamente na vida das minorias sexuais, eróticas e estéticas, situação que será analisada subsequentemente a partir das aqui denominadas "situações-limite".

\section{Corpos indóceis, desejos subversivos: os limites da sexualidade}

Feitos esses esclarecimentos, cabe agora tecer consideraçóes acerca daqueles temas que definitivamente colocam sexo, desejo, perversão e violência na "corda bamba". A principal dificuldade, aqui, talvez resida no fato de que o Direito, do modo como muitas vezes é pensado e "gestado", reduz o sexo e as suas possibilidades a um regime binário: lícito ou ilícito, permitido ou proibido (FOUCAULT, 2012), obedecendo a dispositivos de normalização heterossexual e patriarcal. Mas, como abordar as chamadas "situaçóeslimite" - a exemplo da prostituição, da pornografia, do sadomasoquismo ou da infinitude de práticas eróticas "não convencionais" - a partir daquelas categorias?

É crucial destacar, desde logo, que o mercado do sexo e da prostituição, nesta abordagem, não incluem a prostituição infantil ou a prostituição não consensual, a exemplo da protagonizada no tráfico de pessoas. É evidente, entretanto, que o recrutamento internacional de trabalhadores e trabalhadoras sexuais é um dos efeitos perversos da aceleração dos apetites e curiosidades sexuais da sociedade contemporânea. Contribuíram para tanto, também, as novas formas de comunicação.

Ademais, é sabido que a prostituição abrange também homens (heterossexuais e homossexuais), transexuais, transgêneros, travestis e outras parcelas significativas de minorias sexuais. No entanto, a mulher ainda parece ser o sujeito mais atuante no ramo das economias sexuais, motivo pelo qual a abordagem recairá, por um lado, sobre a prostituição de mulheres, o que não significa que a problemática aqui tecida não se aplique aos outros grupos. Para além disso, não há como deixar de enfrentar o problema do controle social exercido pelo discurso médico e jurídico sobre a homossexualidade em suas distintas manifestações. Tais temas serão estudados nos subitens a seguir. 
4.1 O Direito como a expressão normativa do martelo das bruxas: reflexóes sobre o controle social da sexualidade feminina e a questão da prostituta

Em linhas gerais, é possível dividir as teorizações e a própria militância a respeito como um debate travado entre proibicionistas, regulamentaristas e abolicionistas (RIOS, 2007). O feminismo - seja do ponto de vista teórico, seja do ponto de vista militante apresentou-se ao longo de seu desenvolvimento com diferenças significativas no que diz respeito ao significado da sexualidade. Enquanto alguns grupos tendiam a visualizá-la como um elemento de objetificação feminina, outros a concebiam como uma arena de potencial libertação de mulheres. Neste intervalo - entre objetificação e libertação - existe uma infinitude de outras compreensões acerca do significado emprestado à sexualidade. Dessa maneia, a prostituta foi ora a escrava sexual, oprimida, objetificada e vulnerável, ora o agente mais subversivo da ordem social sexista. Isso significa que enquanto um polo percebe a vinculação da mulher com o sexo como a raiz da opressão e do abuso, o outro a vislumbra como uma estratégia de desestabilizar o poder masculino. Mas a atividade da prostituta efetivamente perpetua a dominação masculina? Até que ponto a violência pode ser explicada pela dominação masculina enquanto tal? Para Piscitelli (2005, p. 14), "as práticas de prostituição, tais como outra forma de mercantilização e consumo, devem ser lidas de maneiras mais complexas que apenas uma confirmação da dominação masculina."

Laura Agustín (2007) tem empregado a expressão mercado do sexo, em lugar de prostituição, com base no fato de que há uma diversidade imensa de trabalhos ou prestação de serviços sexuais, envolvendo desde bordéis, casas de massagem, grupos de swing e sadomasoquismo, linhas telefônicas eróticas, sexo virtual, prostituição "das ruas", acompanhantes "de luxo" etc. Para Agustín (2007), a utilização do vocábulo prostituição restringe e omite toda a pluralidade de possibilidades existentes. Além disso, uma segunda justificativa reside na compreensão de que há um verdadeiro mercado do sexo e utilizar o vocábulo prostituição desvia a atenção da demanda por serviços sexuais, pois existem pessoas efetivamente dispostas a pagar por tais serviços, numa verdadeira lógica de mercado. Piscitelli (2005) acrescenta, ainda, o que poderia ser uma terceira justificativa consistente no fato de que as definiçóes que circulam no imaginário social em torno da prostituição não permitem que sejam compreendidos os diversos tipos de inserção no jogo de oferta e demanda do sexo e da sexualidade, os quais não necessariamente assumem a forma de um contrato explícito de troca de sexo por dinheiro.

Nussbaum (2002) adverte que a maioria das pessoas, na verdade, ganha dinheiro com o uso do corpo. Ou seja, via de regra, quem está empregado e recebe um salário por isso, ganha dinheiro com o uso do próprio corpo. Também para Bataille (2014, p. 159) "não é, na verdade, o pagamento que funda a decadência da prostituta". Nessa senda, que elementos são, de fato, significativamente problemáticos na prática da prostituição em 
comparação com outras atividades profissionais? O fato é que a maioria dos elementos que podem ser considerados como verdadeiramente problemáticos na prostituição são comuns a uma imensa gama de atividades tipicamente exercidas por mulheres pobres.

Para Olivar $(2012$; 2013), é preciso encarar a questão da prostituta a partir de uma perspectiva que politize sexualidade e gênero. Após intensas (e extensas) pesquisas qualitativas de cunho etnográfico, realizadas no contexto latino-americano, o referido autor percebeu que os movimentos destinados a visibilizar a prostituição, emancipando-a, tinham como foco geralmente a promoção da saúde, da autoestima e da cidadania, fazendo inclusive intervençôes educativas e sobre questóes laborais. Sexualidade e gênero, por outro lado, eram temas pouco discutidos. Se Olivar $(2012 ; 2013)$ questiona a deficiência do debate envolvendo sexualidade e gênero dentro do movimento da prostituição, Nussbaum (2002) compreende que tais temas não podem ser desenredados das questóes que permeiam as tentativas das pessoas e especialmente das mulheres pobres de sobreviverem.

De fato, para Nussbaum (2002), a maior diferença entre o exercício da prostituição e de outras profissóes (a autora utiliza como exemplos a operária, a empregada doméstica, a cantora de clubes noturnos, a professora de filosofia, a massoterapeuta e uma fictícia "artista de colonoscopia" ${ }^{8}$ ) reside no fato de que a prostituição é hoje mais amplamente estigmatizada do que os demais labores. E isso por duas razóes: primeiramente por conta de que a prostituição é amplamente taxada de imoral. Em segundo lugar, devido às amarras da hierarquia de gênero, pois há a percepção de que as mulheres e sua sexualidade precisam da dominação masculina, devendo, portanto, estar disponíveis para os homens para que eles possam dar vazão aos seus instintos. Aqui, talvez, seja possível vislumbrar uma afinidade entre as teorizaçóes de Olivar (2012; 2013) e Nussbaum (2002), já que para o primeiro a ausência das discussóes envolvendo sexualidade e gênero são empecilhos relevantes à emancipação das prostitutas.

Às argumentaçóes tecidas por Nussbaum (2002) e Olivar (2012; 2013), poder-seia opor o fato de que a prostituição masculina, inclusive a heterossexual, também é vista como degradante. Entretanto, há aí uma questão relevante, já que nesse caso a suposta degradação ou perversão decorre também da cliente 9 . O problema, então, em maior ou menor grau, deságua na sexualidade feminina, de modo que é preciso dar razão às teorizaçóes de ambos.

8 Mulher que recebe dinheiro para ter seu cólon examinado por instrumentos médicos em fase de experimentação (NUSSBAUM, 2002).

9 Aqui vem a calhar a menção ao longa-metragem nacional "Aquarius", em que Clara, uma mulher de aproximadamente 60 anos, protagonizada por Sonia Braga, "se autoriza" a viver sua sexualidade de forma plena, inclusive com um jovem michê, interpretado por Allan Souza Lima. Além da preocupaçáo política presente em toda a trama, envolvendo a especulação imobiliária em torno de um apartamento simples num antigo prédio de Recife, o longa desconstrói ideias pré-concebidas sobre vida e sexualidade na terceira idade. 
Com efeito, a prostituição e o trabalho sexual somente costumam aparecer como questóes de direitos humanos num espectro negativo, de crime ou violação de direitos. Isso deriva, em boa medida, do fato de que tudo o que diz respeito ao sexo e à sexualidade é envolto por um manto de negatividade, como se falar sobre sexo fosse necessário apenas para prevenir ou, na pior das hipóteses, remediar. A ausência das prostitutas militantes nos espaços formais de ativismo nacional e internacional de direitos humanos é um fato histórico que precisa ser mudado, a fim de que os movimentos pró-abolicionismo possam ser repensados a partir de experiências concretas. Exemplo disso é o fato de que na legislação internacional a menção à prostituição costuma aparecer sempre em documentos ligados ao tráfico de pessoas, aos processos migratórios, à violência, à discriminação, aos problemas de saúde pública, à exploração sexual e ao trabalho escravo. Infelizmente, não tem havido muita disposição política destinada a abordar a prostituiçáo nos documentos tendentes a reger relaçóes laborais, como aqueles estabelecidos no âmbito da Organização Internacional do Trabalho - OIT, por exemplo (OLIVAR, 2012).

Se a prostituição envolve riscos de saúde e de violência, essa exposição é muito maior com a ilegalidade da prostituição, o que impede sua supervisão adequada, aguça o domínio dos cafetóes e desestimula o controle de adequadas condiçóes sanitárias. "Certamente os riscos de violência podem ser muito melhor controlados quando a polícia é um aliado das prostitutas, em vez de um opressor.” (NUSSBAUM, 2002, p. 32).

É ilustrativo que a prostituição, como um campo possível de trabalho para a mulher, depende do distanciamento que ela (como filha/esposa/mãe) consegue manter do seu erotismo. A política de tolerância em face do trabalho sexual traz consigo muito da ética do trabalho e da família. Por isso, quando saem em defesa do seu trabalho, muitas prostitutas atuantes em regióes vulneráveis, como é o caso dos países latino-americanos, entoam um discurso de pobreza/autonomia financeira feminina e de responsabilidade maternal ou cidadã, consistente nos questionamentos em torno de "quem vai pagar minhas contas?" e "quem vai sustentar meus filhos ou pagar meus impostos?". Evidenciase, assim, uma justificativa teoricamente mais aceita envolvendo o fato de que tais mulheres se tornaram prostitutas em contextos de necessidade (OLIVAR, 2012; 2013).

É por isso que, para Olivar $(2012 ;$ 2013), fortemente inspirado pela prostituta brasileira Gabriela Leite ${ }^{10}$, a expressão "puta” assume especial relevância, pois é antes o estigma da puta (e náo da prostituta), enquanto categoria moral de gênero, que embasa a discriminação e a violência contra as prostitutas. Embora a palavra circule no imaginário íntimo de parceiros e parceiras com relativa liberdade, na cena pública

10 Gabriela Leite foi uma figura ímpar no cenário da prostituição brasileira. Falecida em 2013, aos 62 anos, fundou a grife (ou "putique") Daspu - em clara referência (possivelmente provocativa) à boutique de luxo Daslu, também brasileira - e a ONG DaVida, símbolo no fortalecimento da cidadania das prostitutas (LEITE, 2009). Tamanha é a importância de sua luta que o Projeto de Lei no 4.211/2012, que regulamenta a atividade dos profissionais do sexo no Brasil, leva o seu nome. O PL, de autoria do ex-Deputado Federal Jean Willys (PSOL/ RJ), foi arquivado em 31 de janeiro de 2019. 
isso não ocorre. Nessa senda, utilizar o adjetivo significa uma (micro)resistência calcada em políticas identitárias. Na realidade, o estigma da puta sustenta uma violência que se exerce não somente contra as prostitutas, mas contra todas as mulheres que assumem um comportamento supostamente mais autorizado sexualmente. Ou seja, o objeto de tais violências consiste nas práticas e performances (especialmente femininas) vinculadas à expressão erótica, à devassidão, à vadiagem, à perversão e ao uso do sexo e do corpo como um meio de ascensão social e simbólica ${ }^{11}$. Isso explica o motivo pelo qual a prostituta (ou a mulher sexualizada) é vítima de violências das mais diversas ordens.

Com efeito, a prostituta desafia a ponderaçáo da liberdade sobre o próprio corpo no campo econômico (RIOS, 2007). "Pensar a prostituição no marco dos direitos sexuais implicaria afirmar, criar, a existência de 'sexualidade', de erotismo, na prática das mulheres prostitutas." (OLIVAR, 2012, p. 100). Essa tarefa, entretanto, tende a ser tudo menos tranquila. Isso porque é justamente no marco da expansão do dispositivo da sexualidade foucaultiano (2012) que a prostituição ganhou contornos de perversão. Quer dizer, a prostituta sexualizada, que goza, que gosta do que faz, não raras vezes é tida como devassa, perversa, anormal. Daí porque ser complicado (re)colocar a sexualidade na conduta da prostituta, justamente porque foi retirando-lhe essa percepção que nasceu a noção de prostituta organicamente comprometida com o Estado, com a família e com os preceitos morais e sanitários. Por isso, Olivar (2012) afirma que a estratégia do movimento tem sido o "náo-falar". Em certa medida, revisitam-se conceitos duais do racionalismo que separou corpo e mente, para fazer da prostituta apenas razão, desassociando-a do gozo, do corpo organicamente considerado, das pulsóes e dos prazeres.

É por isso que a regulamentação profissional e a afirmação da identidade profissional (isoladamente) não são mecanismos suficientemente capazes de desconstruir o estigma, tampouco para consolidar a dignidade humana e a cidadania da prostituta. Nesse sentido, Olivar (2012) adverte que é preciso pensar a prostituiçáo como um direito sexual, de modo que a categoria dialogue e seja somada à luta por direitos fundamentais e laborais. Isso, entretanto, só pode ocorrer se o movimento encarar de vez o tema do gênero e da sexualidade, integrando-os criativamente à sua plataforma política calcada no trabalho.

Sobre a questão da autonomia, Nussbaum (2002, p. 34) assevera que outras formas de serviços físicos também impóem redução da autonomia do sujeito. Por isso, a filósofa estadunidense sugere que "deveríamos, sim, refletir sobre formas de promover mais controle sobre a escolha das atividades, maior variedade e mais humanidade de um

11 Se na pré-modernidade o sujeito tinha um lugar pré-determinado, nada podendo fazer a respeito, a partir da Modernidade isso se altera, de modo que as relaçôes afetivas englobam uma possibilidade de escolha, de eleição do parceiro ou parceira a partir de aspectos emocionais, mas que também levam em consideração estratégias econômicas de mobilidade social (ILLOUZ, 2011). 
modo geral nos tipos de trabalho que estão de fato disponíveis para pessoas com pouca educação e poucas opçôes".

Por fim, dois argumentos parecem centrais na teorização de Nussbaum (2002) para derrubar a ideia de que a criminalização é a melhor maneira de emancipar as prostitutas. Saindo em defesa da legalização da atividade, a autora lembra que a maioria das culturas abarca relaçóes afetivas que guardam um importante aspecto comercial. Mesmo o casamento possui uma conotação visivelmente mercantil. "Um pagamento podia entrar no ciclo das trocas cerimoniais que não acarretava o aviltamento próprio ao comércio" (BATAILLE, 2014, p. 159).

Elizabeth Anderson (1993), forte crítica da prostituição e defensora ferrenha da criminalização, alega que a prática dificulta o estabelecimento de relações de intimidade e comprometimento. $\mathrm{O}$ que significa que supostamente não é possível permitir trocas mercantis de sexualidade sem interferir negativamente em aspectos importantes da sexualidade não comercial. A isso, Nussbaum (2002) contra-argumenta lembrando que não se pode esquecer da noção que circula no imaginário social de que a prostituta tem uma função social, pois proporciona ao desejo masculino uma vazão seguramente desvalorizada em benefício da manutenção da família - repristinando, portanto, em pleno século XXI, a visão de Santo Agostinho, que aprovava a conduta porque ela ajudava a proteger as mulheres respeitáveis e honrosas do desejo masculino excessivo (STEARNS, 2010).

É preciso admitir, de uma vez por todas, que nada há de errado em ganhar dinheiro com o uso do próprio corpo. O que parece errado é que, de fato, poucas pessoas tenham a opção genuína de utilizar seu corpo, em seu trabalho, da forma "verdadeiramente humana” a que fazia menção Marx (1991).

O estigma tradicionalmente atribuído à prostituição é baseado em uma mistura de crenças muitas das quais não são racionalmente justificáveis e que deveriam ser veementemente rejeitadas pelas feministas: crenças sobre o caráter maligno da sexualidade feminina, o caráter ávido da sexualidade masculina, o caráter essencialmente marital e reprodutivo das "boas" mulheres e do sexo "virtuoso". (NUSSBAUM, 2002, p. 46).

Apesar das inúmeras dificuldades ainda existentes no que diz respeito ao reconhecimento da identidade profissional (e pessoal) de profissionais do sexo, é preciso considerar que a prostituição se tornou, paulatinamente, um campo menos subversivo, proibido ou lúdico do ponto de vista da "clientela", pois a prática passa a ser, ao menos teoricamente, mais aceita (ou minimamente tolerada) no imaginário social. Com efeito, as "zonas de tolerância" se alastram, ainda que muito lentamente, para campos como o adultério, a masturbação, a prostituição, a pornografia e a homossexualidade (GREGORI, 2014).

Em seu lugar, portanto (e como reflexo de uma sociedade efêmera, fluida e angustiada), surgem propostas mais ousadas, a exemplo das práticas BDSM (bondage, 
disciplina, dominação, submissão, sadismo e masoquismo), do sadomasoquismo, do fetichismo, do consumo de objetos eróticos (boutiques eróticas e sex shops), da homoeroticidade e das experiências intergeracionais que envolvem envelhecimento - as quais emergem hoje como diferentes (e nem por isso tão inovadoras) formas de subjetividade de indivíduos que se propóem a estar no mundo com um forte componente sexual.

No que diz respeito a tais modalidades de erotismo - aqui denominadas "não convencionais", "transgressoras" ou "subversivas" - é conveniente mencionar, desde logo, que classificações e conceituaçóes estanques implicam a castração de possibilidades, considerando o vasto leque comportamental factível. Toda tentativa (e é sempre uma tentativa) de rótulo e diagnóstico a partir da neurose, da psicose, da perversão, da parafilia etc. faz com que a singularidade do sujeito se perca em meio à ordenação do caos (MCDOUGALL, 1997). Nesse sentido, o psicanalista Yalom (2016, p. 224) atenta para o fato de que

mesmo o mais liberal sistema de nomenclatura psiquiátrica comete uma violência contra a essência da pessoa. Se nos relacionamos com as pessoas acreditando que podemos categorizá-las, não iremos nem identificar nem cuidar das partes vitais do outro que transcendem a categoria. O relacionamento possível sempre supóe que o outro jamais pode ser inteiramente conhecido.

Nessa perspectiva, chama atenção o fato de que a Classificação Estatística Internacional de Doenças e Problemas Relacionados com a Saúde (CID10), sob a rubrica F65 inclui, ainda hoje, na condição de parafilias, o fetichismo, o travestismo fetichista, o exibicionismo, o voyeurismo, a pedofilia, o sadomasoquismo e outras práticas. Pode não haver muita controvérsia atualmente no que diz respeito ao corpo da criança e da (in)acessibilidade que lhe é tão particular (e deve, sim, sofrer regulação). Mas a proposta da CID10-F65 é um "prato cheio" de patologizaçóes relativas ao que seria um comportamento sexual anormal, deixando margem para o enquadramento de toda ordem de transtornos de preferência sexual, inclusive para os não especificados (CID10-F65.9) ${ }^{12}$. Vale lembrar que a CID10-F64 e a CID10-F66 também abordam, numa concepção um tanto quanto questionável, desordens de identidade de gênero e desordens de preferência sexual, respectivamente (OMS, 2016).

Não é por acaso que Martins e Ceccarelli (2003) preocupam-se com que essa abrangente classificação sirva à estigmatização e à violência contra as minorias sexuais, pois é tarefa extremamente custosa diferenciar os parafílicos "autorizados" dos "sociais", ou seja, daqueles cujos atos são considerados não somente moralmente inaceitáveis, como também ilícitos (ROUDINESCO, 2008). E isso justifica a menção de Foucault (2014a, p. 146) ao fato de que, a partir do século XIX, operam-se mecanismos de apelo que

12 O projeto "ReviseF65" propóe a retirada do fetichismo, do travestismo e do sadomasoquismo como diagnóstico psiquiátrico da classificação proposta pela OMS. 
sinalizam para a necessidade de "revelação institucional e custosa da sua sexualidade ao psiquiatra, ao psicanalista e ao sexólogo". O objetivo confesso, aduz Roudinesco (2008), é dar um fundamento antropológico ao sexo e estabelecer uma separação radical entre uma sexualidade considerada normal, alicerçada na saúde, na procriação e na restrição do prazer, e uma sexualidade perversa, problemática, porque situada ao lado da esterilidade, da morte, da doença, da inutilidade e, o que talvez seja mais grave, do gozo.

\subsection{As narrativas médica e jurídica e o controle social da homossexualidade}

Ao longo de milhares de anos, para garantir a permanência de estruturas de dominação masculina e heterossexual, foi sendo construída uma representação social fundada na naturalidade desta dominação. Esta face do problema é bem menos percebida pela ciência jurídica do que por outras áreas das ciências sociais, especialmente pela sociologia e pela antropologia cultural. O Direito apreende, com duvidosa acuidade, na maioria de suas análises, de viés amplamente dogmáticas, talvez a parte relativa à regulação do problema, mas desconhece quase que em sua total amplitude as causas e origens destes estados de dominação. E a partir de uma visão obtusa da totalidade do fenômeno, o que tem acontecido é que os sistemas jurídicos têm demorado demasiadamente na provisão das demandas sociais de grupos como os homossexuais, em relação a medidas que garantam espaços de emancipação social.

É preciso que reconheçamos que o elemento cultural desempenha um papel proeminente na determinação do acontecimento destes sistemas de dominação, visto que não há qualquer essencialidade natural/sexual que determine a permanência de estados de dominação masculina e heterossexual e a consequente negação de direitos para mulheres e homossexuais. Para melhor entender estes processos dominatórios é preciso prestar muito mais atenção aos processos de socialização, constituídos a partir da formação de personalidades de base, do que propriamente ao ambiente, como faziam os sociólogos de Chicago. As normas, os costumes, as instituiçóes... formam, com efeito, um sistema cultural específico e relativo, que forja a personalidade de base dos indivíduos que compóem determinadas sociedades.

Nesse ponto, a evolução das ciências sociais demonstrou, contrariamente ao sentido evolucionista das espécies aproveitado pelos darwinistas sociais, que o processo cultural nada tem a ver com aspectos biológicos ou geográficos, quedando por terra a construçáo retórica do colonialismo que se apropriava de conceitos como raça, gênero e sexualidade para classificar os sujeitos na ordem política da sociedade, tal como referido anteriormente. Os antropólogos são categóricos em afirmar que a construção cultural é um processo de endoculturação. Felix Keesing é taxativo quando defende que "não existe correlação significativa entre a distribuição dos caracteres genéticos e a distribuição dos comportamentos culturais" (apud LARAIA, 2001, p. 17). Seu posicionamento está 
referendado pela declaração da Unesco redigida por diversos especialistas em Paris no ano de 1950. Roque de Barros Laraia reproduz o parágrafo dez do documento que se compatibiliza totalmente com o entendimento de Kessing, valorizando o processo de endoculturação na definição da história cultural de cada grupo: "os fatores que tiveram um papel preponderante na evolução do homem são a sua faculdade de aprender e a sua plasticidade." (LARAIA, 2001, p. 18).

A obra desse autor é recheada de exemplos que afastam o dimorfismo sexual como fator preponderante do comportamento humano, sendo que a principal assertiva nesse sentido diz respeito à comprovação de que atitudes que em determinada cultura são exclusivas dos homens, em outras competem unicamente às mulheres. Apenas para fins de ilustração, cabe discorrer sobre dois emblemáticos casos envolvendo tribos indígenas. Quando pensamos em tarefas que exigem esforço físico, logo associamo-las à responsabilidade do macho, porém, na região do Xingu, são as fêmeas que transportam baldes de água na cabeça. Já quando as mesmas tarefas são de cunho afetivo-puerperal, geralmente relacionamo-las às genitoras. Mais um equívoco: na comunidade Tupi, assim que parido o filho, no lugar do calor do peito materno, o aconchego é paternal e nas redes de dormir (LARAIA, 2001).

Em soluçáo de continuidade para melhor compreendermos o problema do engendramento social de sistemas de dominação da sexualidade, citemos alguns outros relevantíssimos trabalhos que indicam este mesmo caminho. Em primeiro lugar, o trabalho de Kardiner, denominado "O indivíduo em sua sociedade". Ao contrário de Margaret Mead, Bronislaw Malinowski, Roheim Geza ou Georges Devereux, Abrão Kardiner não era um etnólogo de campo, mas um profissional da antropologia que se baseou no trabalho etnográfico de seus amigos e contemporâneos Ruth Benedict, Cora Dubois e Ralph Linton, para propor uma análise global dos modos de adaptação do homem à sociedade. Junto deles, e desde uma perspectiva culturalista, ele desenvolveu, no período entre guerras, a corrente "Cultura e Personalidade", uma das vias de implantação da psicanálise nos Estados Unidos, ao lado do neofreudismo. À ideia freudiana da estruturação psíquica própria de cada sujeito ele opôs a de uma estruturação psicológica característica de todos os membros de uma cultura, e a denominou de personalidade básica. Desembaraçada de seu biologismo, a temática freudiana inspira diretamente as análises de Kardiner (1969). Às três instâncias do psiquismo humano mapeadas por Freud que se apresentam ligadas entre si (Ego que é o elemento mediador entre o Id - reservatório das pulsóes libidinais - e o Superego - lugar da interiorização de uma moral definida socialmente), Kardiner cola o culturalismo e define a personalidade (equivalente do Ego) como a expressão socializada de uma natureza humana universal $(=\mathrm{Id})$, modelada por valores, por normas, por instituiçóes, etc., característicos de uma cultura particular (= Superego). 
Kardiner acredita, mais precisamente ainda, que toda sociedade possui um conjunto de instituições perenes que tem por função socializar os indivíduos. Assim, tendo por base um material natural idêntico para todos os seres humanos (instintos), essas instituiçóes imprimem uma marca específica, a de uma personalidade comum que é partilhada de maneira exclusiva pelos membros de uma dada sociedade e na qual vêm, depois, se enxertar as variaçóes individuais. Segundo Kardiner (1969), convém finalmente distinguir as instituiçóes primárias (estrutura familiar, modo de alimentação, desmame dos filhos pequenos, educaçáo para a limpeza e tabus sexuais) que contribuem diretamente para a produção de uma "personalidade de base" e definem a relação entre pais e filhos, das instituiçóes secundárias (religióes, mitos, sistema político, econômico, cognitivo, etc.), que são o produto de frustraçóes engendradas pelas instituiçóes precedentes e podem ser analisadas como projeçóes simbólicas compensatórias (LALLEMENT, 2008).

Se o trabalho de Kardiner já minimiza os efeitos biológicos e ambientais sobre os processos de socialização, deslocando o foco de análise para as variáveis culturais, o trabalho de Margaret Mead, situado no campo da antropologia cultural, acentua ainda mais a importância destes últimos elementos. Em sua obra "Costumes e Sexualidade na Oceania”, resultado de suas pesquisas de campo, Mead (1963) mostra claramente a plasticidade da natureza humana e mais particularmente o caráter redundante das oposiçóes biológicas de sexo em face do condicionamento social e cultural. Mead analisou os traços característicos que três povos primitivos atribuem normalmente à personalidade de cada sexo. Nos Arapesh, tanto homens como mulheres, ou os seus traços, vistos pelo ângulo familiar, parecem do tipo materno, e são femininos caso considerados do ponto de vista sexual. Rapazes e moças aprendem, desde a mais tenra idade, a adquirir o sentido da solidariedade, a evitar atitudes agressivas, a consagrar a atenção à necessidades e aos desejos dos outros. Nem os homens nem as mulheres sentem a sexualidade como se fosse a força poderosa da qual seriam escravos. Quanto aos Mundugumor, ao contrário, mostraram-se, não importa o sexo a que pertençam, de um temperamento brutal e agressivo, de uma sexualidade exigente: nada, neles, de carinhoso e maternal. É um tipo de temperamento que associaríamos, entre nós, a um caráter obstinado e violento. $\mathrm{O}$ terceiro povo primitivo investigado, os Chambuli, deram uma imagem inversa daquilo que ocorre em nossa sociedade. Aí, a mulher é o parceiro dominante; tem a cabeça fria, é ela que pilota a barca; quanto ao homem, é, dos dois, o menos capaz e o mais emotivo. Para Mead (1963), de tal confronto se destacam conclusóes bem precisas. Se algumas atitudes que consideramos como tradicionalmente associadas ao temperamento feminino, tais como a passividade, a sensibilidade, o amor aos filhos, podem táo facilmente ser típicas de homens de uma tribo, e numa outra, ao contrário, ser recusadas pela maioria dos homens como também das mulheres, não temos já razão nenhuma para crer que sejam irrevogavelmente determinadas pelo sexo do indivíduo. E esta conclusão se impóe com tanto mais força quando se vê como os Chambuli inverteram os papéis, embora 
conservem oficialmente instituições patrilineares. Mead afirma, ainda, que muitos dos traços de caráter que qualificamos como masculinos ou femininos são, em boa parte, se não na totalidade, determinados pelo sexo de uma maneira tão superficial como são as roupas, os modos, os penteados que uma época fixa para este ou aquele sexo. Fechando esta análise, Mead conclui que somos forçados a concluir que a natureza humana é sumamente maleável, obedece fielmente aos impulsos que o corpo social lhe comunica.

As comunicaçóes sociais que têm garantido a estabilidade das estruturas de dominação patriarcais e heterossexuais têm se valido do que Foucault (1984) chama de "dispositivos de sexualidade" que respondem a objetivos estratégicos dominantes bem definidos, que trabalham através de imperativos estratégicos e se apresentam como matrizes deste dispositivo. Estes dispositivos se compóem de um conjunto heterogêneo que engloba discursos, instituições, organizações arquitetônicas, decisões regulamentares, leis, medidas administrativas, enunciados científicos, proposições filosóficas, morais e filantrópicas (FOUCAULT, 1984, p. 244).

$\mathrm{Na}$ parte que toca aos discursos na composição dos dispositivos de dominação da sexualidade, a medicina e o Direito têm cumprido um papel relevantíssimo. Inicialmente, como bem lembra Foucault (2012, p. 32), a medicina, por intermédio de "doenças de nervos"; em seguida, a psiquiatria, quando começa a procurar - do lado da "extravagância", depois do onanismo, mais tarde da insatisfação e das "fraudes contra a procriação", a etiologia das doenças mentais e, sobretudo, quando anexa ao seu domínio exclusivo, o conjunto de perversóes sexuais. Exemplo bastante significativo sobre a estruturação do discurso da medicina sobre a sexualidade, especialmente durante o século XIX, mas que perdura ainda hoje, pode ser localizado no campo da medicina forense, mais especificamente na psiquiatria. De artigo publicado na Revista Psiquiatría Forense, Sexología y Praxis, segue o seguinte extrato que trata de algumas definiçóes e classificaçóes referentes à impotência sexual, e que resume de forma bem clara uma parte importante de um dispositivo de dominação da sexualidade:

La llamada" impotencia sexual" como incapacidad o insuficiencia del varón para realizar el acto sexual (coito) completo y adecuado, clásicamente se dividía en impotencia:

a) Fecundante: esterilidad masculina, b) Coital: incapacidad de copular.

En la actualidad de acuerdo al conocimiento del ciclo de respuesta sexual, se describen sexológicamente distintas formas de disfunción sexual del varón:

a) del deseo o apetito sexual b de la erección (incapacidad de penetración vaginal) c) de la eyaculación d) del orgasmo

Por lo tanto las formas de expresión más habituales de observar de las disfunciones sexuales son:

a) Falta deseo: sin interés (anafrodisia) o con interés (impotencia erótica)

b) Deseo normal pero con temor coital (mixofobia)

c) Deseo normal sin erección (impotencia erectiva) 
d) Erección insuficiente con eyaculación "ante porta" (impotencia copulativa)

e) Erección penetrativa con eyaculación muy rápida (eyaculación precoz)

f) Erección penetrativa sin eyaculación (impotencia eyaculativa o aneyaculación)

g) Erección penetrativa y eyaculación sin orgasmo o con sensación dolorosa (impotencia orgásmica). (ROMI, 2008, p. 35-36, grifo nosso).

O que chama a atenção na passagem acima é a adoção de um conceito de desejo normal, provavelmente relacionado ao desejo heterossexual. Aquele que sente atração por indivíduos do mesmo sexo, especialmente homens que sentem atração por homens e que em função deste desejo não conseguem ter ereções com mulheres, mas somente em relaçóes sexuais mantidas com outros homens são considerados impotentes.

Paradigmático é o escrito enciclopédico do psicanalista austríaco Otto Fenichel, denominado "Teoria Psicanalítica das Neuroses", datado do ano de 1945, no qual expóe um extenso capítulo sobre "Perversóes e Neuroses Impulsivas", cujo conteúdo, altamente dogmático, aborda temas como princípios das perversóes, perversóes em geral, homossexualidade masculina e feminina, fetichismo, travestismo, exibicionismo, voyeurismo, corte de tranças, coprofilia, perversões orais, submissão sexual extrema, sadismo, masoquismo e, ao final do capítulo, propóe uma terapêutica psicanalítica das perversóes (FENICHEL, 1981).

Estes conceitos foram trazidos, lenta e gradualmente, para dentro da medicina legal, disciplina acessória ao direito civil e ao direito penal. Agostinho J. de Souza Lima, em seu "Tratado de Medicina Legal”, editado no ano de 1924, ao esboçar comentários sobre a homossexualidade, tanto masculina quanto feminina, referindo-se à violência carnal, entre as quais inclui a pederastia, diz o seguinte:

Entre ellas compreende pela primeira vez o código brasileiro os atentados praticados com pessoas do mesmo sexo: a tribadia ou amor lesbico (entre mulheres), e a pederastia ou amor grego (entre homens).

\section{$[\ldots]$}

Aqui eu poderia, seguindo o exemplo de quase todos os tratadistas, percorrer e comentar cada uma destas e outras muitas variantes sugeridas pela aberraçấo da sensualidade humana, ou manifestamente doentia ou supinamente degradante. Esta digressão pornográfica, porém, aproveitaria mais à curiosidade erótica do que ao interesse scientifico, particularmente à pratica medico-legal, que não me consta ter sido chamada entre nós a se exercitar sobre factos dessa natureza, a não ser os de coito anal, especialmente os que se referem à pederastia, de cuja semiótica e exame pericial, me ocuparei adeante (LIMA, 1925, p. 551).

Exemplo também bastante demonstrativo deste discurso obtuso, de interseção entre o discurso médico e o discurso legal sobre a sexualidade nos é dado por Almeida Jr. e Costa Jr. (1978), na obra denominada "Liçóes de Medicina Legal". Ao tratar do capítulo referente à sexologia forense, estes autores, ao mencionarem as principais circunstâncias em que, por faltar a ereção, existe a impotência coeundi funcional, citam, no item 5, 
as perversóes sexuais, consideradas como tais a masturbaçáo, o homossexualismo, o feiticismo, etc.

Também o discurso normativo penal ocupou-se e ainda se ocupa fortemente da sexualidade. Inicialmente, com previsôes de crimes "crapulosos" e antinaturais, mas, posteriormente, aproximadamente a partir da metade do século XIX, também oferecendo à jurisdição penal pequenos atentados, ultrajes de pouca monta, "perversóes" de pouca monta, o discurso repressivo penal ainda permanece vigente contemporaneamente, havendo inúmeros países do mundo que, por forte influência religiosa, punem a homossexualidade até mesmo com pena de morte. Para não pensarmos, equivocadamente, que estamos muito distantes desta cultura repressiva, no Brasil ainda permanecem traços desta cultura jurídica persecutória e punitiva dos homossexuais. Vejamos, por exemplo, o art. 235 do Código Penal Militar brasileiro - em nosso entendimento completamente inconstitucional -, ainda em vigor, o qual prescreve:

Art. 235. Praticar, ou permitir o militar que com êle se pratique ato libidinoso, homossexual ou não, em lugar sujeito a administração militar:

Pena - detenção, de seis meses a um ano.

O que é importante reter destas referências discursivas? O seu caráter controlador, repressivo e punitivo, com finalidades de estruturação de relações de dominação, onde políticas sexuais eram e são executadas através de conjuntos estratégicos que alimentam e são alimentadas por dispositivos específicos de saber e poder sobre o sexo. Particularmente em relação ao homossexuais, a estratégia utilizada foi a psiquiatrização do prazer perverso no campo da medicina e as puniçóes no plano jurídico.

Assim, o que se pode concluir, num primeiro momento, é que a racionalidade prática do Direito e a racionalidade cognitivo-instrumental da ciência, especialmente da medicina, associaram-se náo para um manejo reconstrutivo dos excessos perpetrados contra os homossexuais a partir destes discursos, mas, num sentido contrário, funcionaram como dispositivos altamente repressores. Ciência e Direito foram, neste aspecto, reguladores e controladores; de forma alguma emancipadores.

\section{Diferença e desejo: duas categorias de ruptura das violências jurídicas contra o Direito Fundamental à livre manifestaçáo da sexualidade}

Uma análise que envolva o erotismo não convencional deve levar em consideração as transformações proporcionadas pelo advento da internet e, mais recentemente, pelos smartphones e seus aplicativos de conversação em tempo real. É que para o bem e para o $\mathrm{mal}^{13}$, a rede mundial de computadores alterou significativamente a dinâmica das relações interpessoais (MISKOLCI, 2017). Mais do que isso, ela tornou-se um importante campo

13 Isso porque não se desconhece o fato de que a internet possui uma faceta um tanto quanto perversa, com a 
para formação de uma "subcultura virtual" de minorias sexuais, de modo que o uso da internet foi e segue sendo fundamental para a firmação da cultura BDSM, das práticas sadomasoquistas, da pornografia, da comercialização de produtos eróticos etc., até mesmo em virtude da noção de reconhecimento que ela possibilita quando se encontram os "semelhantes".

Prescindindo do contato corporal, a internet traduz comportamentos, atributos, sentimentos, interesses e tendências ou preferências pessoais a partir de perfis e dos dados, sinais e signos neles presentes e por eles comunicados (MARTINS, CECCARELLI, 2003). Isto é, "na situação vigente na internet, primeiro as pessoas são apreendidas como um conjunto de atributos, e só depois apreendem - em etapas gradativas - a presença corpórea do outro." (ILLOUZ, 2011, p. 113) ${ }^{14}$.

O comportamento erótico "não convencional" desestabiliza noções importantes de sexo, gênero e sexualidade, sobretudo porque há uma zona fronteiriça e nebulosa na qual (co)habitam norma e transgressão, consentimento e abuso, prazer e dor/violência. $\mathrm{O}$ desejo, por sua vez, parece ser uma categoria central para a análise dessas práticas. Maria Filomena Gregori (2014, p. 50) assevera que "o desejo é feito daquilo que provoca, que incita e que assinala a diferença." Portanto, gênero, idade, cor, ascendência, "raça" e classe social configuram posiçóes sociais de desigualdade em relaçóes de abuso, mas também nas trocas que proporcionam prazer, afetividade e pactos saudáveis.

Nesse sentido, é ilustrativo que tais marcadores sociais de gênero, no caso das fantasias eróticas, relacionem feminilidade às atividades profissionais nas quais estão imbricadas assimetrias ligadas à subalternidade e ao controle - enfermeira, empregada doméstica, colegial, tigresa, coelhinha, bombeira, militar, policial -, retomando a questão do cuidado, da conotação pedofílica, da sensualidade animal ou do domínio ${ }^{15}$ (GREGORI, 2016). São, portanto, experiências que se atrevem a manipular (ou manter por completo) os conteúdos e inscrições sociais imbricados na sexualidade e nas suas assimetrias no que diz respeito a gênero, "raça", idade e classe social.

divulgação de pedofilia, cenas de estupro (mais recentemente abarcando até mesmo o chamado estupro virtual) e outras práticas não consensuais e violadoras de direitos de toda ordem.

14 Illouz (2011) assevera que o espírito racionalista do mercado se inseriu inteligentemente no mundo e na gramática dos afetos, de modo que se os afetos foram racionalizados pela lógica típica do capitalismo, é verdade também (e paradoxalmente) que o mundo dos negócios foi reconfigurado, na Modernidade tardia, pela institucionalização da psicologia e da terapia nos empreendimentos e no corporativismo.

15 E acerca do tema do domínio ou do poder sobre o outro Nietzsche (2012, p. 64) questiona se "nosso amor ao próximo - não é ele uma ânsia por uma nova propriedade?" e prossegue aduzindo que "é o amor sexual que se revela mais claramente como ânsia de propriedade: o amante quer a posse incondicional e única da pessoa desejada, quer poder incondicional tanto sobre sua alma como sobre seu corpo, quer ser amado unicamente, habitando e dominando a outra alma como algo supremo e absolutamente desejável." Com efeito, as relaçôes sexuais em nada diferem de outras relações, pois constituem-se elas também em uma luta incessante pelo poder, de modo que o amor não pode ser tido como o oposto de egoísmo, pois é, talvez, a mais direta expressão de que dispóe o egoísta. Desejar o outro é, afinal, fazer dele objeto. 
As pesquisas de Gregori (2014) também evidenciam que as interaçóes que os parceiros estabelecem não são pautadas unicamente pelo sexo biológico, de modo que ser homem ou mulher não é critério de dominação ou submissão. Por outro lado, é preciso admitir que as tensóes de gênero permanecem presentes, inclusive de modo exagerado, caricatural. Nesse sentido, para Anne Mcclintock (1994, p. 89):

Yet, on the contrary, with its exaggerated emphasis on costume and scene, S/M performs social power as scripted, and hence as permanently subject to change. As a theater of conversion, $\mathrm{S} / \mathrm{M}$ reverses and transmutes the social meanings it borrows, without finally stepping outside the enchantment of its magic circle. In $\mathrm{S} / \mathrm{M}$, paradox is paraded, not resolved.

Gregori (2014) assevera que o senso comum costuma acreditar que existam mais dominadores(as) do que submissos(as), quando na verdade seus trabalhos etnográficos evidenciaram que o que ocorre é justamente o oposto, sendo inclusive "muito comum ouvir no clube uma queixa em relação à exiguidade de pessoas que ocupam essas posiçóes [de dominação]" (GREGORI, 2014, p. 63), pois aquele ou aquela que assume a condição de dominação tem o encargo de criar um conjunto de prescriçóes que articulem (também) os desejos do(a) submisso(a), numa atividade quase que pedagógica.

O fato é que consentimento e vulnerabilidade são termos centrais no que diz respeito aos direitos e práticas sexuais ${ }^{16}$. E nesse aspecto há que se ter clareza de que a sociedade é constituída de sujeitos desiguais, daí porque da dificuldade de definir se é genuíno o consentimento (GREGORI, 2014). A questão do consentimento é tão elementar que a ausência dele no caso do chamado pornô bizarro - denominação de DíazBenitez (2012) para o pornô com animais - situa esse tipo de prática erótica nos lugares mais ignóbeis da hierarquia sexual e na produção fílmica de pornografia. Isso explica o motivo pelo qual, no tocante às experiências sadomasoquistas, Gregori (2014; 2016) tenha percebido uma preocupação sempre constante entre os praticantes de que seus envolvimentos se constituam em algo "são, seguro e consensual”. Para tanto, cumprem-se procedimentos ou protocolos ${ }^{17}$, os quais permitem (embora nem sempre) que haja um afastamento da noção de violência, viabilizando o prazer.

Uma última questáo a ser levantada sobre o BDSM e outras práticas ainda controversas envolve o risco de que elas eventualmente possam fomentar a desigualdade social de gênero e sexualidade. $\mathrm{O}$ capitalismo contemporâneo e o neoliberalismo produziram a noção de transgressão sexual a partir de situaçóes-limite que proporcionam determinadas cenas como espaços seguros para os desejos privados que alicerçam desigualdades ${ }^{18}$. Nesse sentido, a socióloga Eva Illouz (2014) recentemente curvou-se à

16 É coerente lembrar, contudo que essas categorias algumas vezes podem se constituir como empecilhos ao exercício da sexualidade no caso das pessoas com deficiência.

17 Tais protocolos incluem, por exemplo, a inclusão de uma "palavra de segurança" (uma espécie de senha, safeword) previamente acordada entre os envolvidos numa prática BDSM para indicar que se atingiu determinado limite.

$18 \mathrm{O}$ capitalismo tem uma relação carnal com as forças de poder. $\mathrm{O}$ consumo, nessa perspectiva, apresenta 
tentativa de compreender o sucesso de vendas da trilogia "Cinquenta tons de cinza", de E. L. James. Os romances giram em torno da relação entre o bilionário Christian Grey e Anastasia Steele, uma jovem de 21 anos que aceita tornar-se o objeto de submissão de Grey em cenários sadomasoquistas. Uma primeira observação feita por Illouz (2014) que pode justificar o sucesso de vendas é a de que Steele não é dominada ou subordinada a Grey em outras esferas da vida, limitando o componente "submissão" ao campo da sexualidade.

É que em contextos de maior igualdade entre homens e mulheres, torna-se cada vez mais difícil definir papéis sociais masculinos ou femininos. Essa circunstância, por sua vez, gera uma angústia que não estava táo evidente nas relaçóes de desigualdade, tendo em vista que na lógica patriarcal não havia escolhas a fazer, pelo menos náo do ponto de vista da emancipação feminina. Portanto, a autora conclui que o sadomasoquismo de "Cinquenta tons de cinza" proporciona uma soluçáo simbólica - de conforto e resgate de valores agora desestabilizados - para os conflitos e tensóes que foram trazidos pelas relações mais igualitárias entre homens e mulheres.

Sua análise é especialmente relevante na medida em que permite reflexóes acerca das consequências do erotismo contemporâneo na vida sexual e afetiva de homens e mulheres. Para a socióloga marroquina, o feminismo ainda não percebeu que a luta pela liberdade sexual para as mulheres pode ser, antes e na verdade, a consagraçáo de um modelo masculino de sexualidade. Essa percepção também pode ser encontrada nas entrelinhas da obra de Gregori (2016, p. 203), para quem é realmente difícil prever o impacto dos novos erotismos sobre as convençóes de gênero e as sexualidades, pois por um lado, essas transformações

permitiram expandir a tolerância e o âmbito de experimentaçôes sexuais, como fica claro pela diversidade de usos de bens eróticos. De outro lado, há o risco de responsabilizar as mulheres pela manutenção da felicidade sexual de relacionamentos amorosos, reforçando uma etiqueta erótica composta por convençōes ainda fortemente heteronormativas.

Isso porque vem se sustentando muito fortemente nas sociedades contemporâneas a noção segundo a qual somente é verdadeiramente feliz, emancipada e independente a mulher que vive sua sexualidade intensamente. Soma-se a isso o entendimento de Illouz (2016) de que há, ainda, distinçóes marcantes entre a sexualidade masculina - mais voltada para o sexual casual - e a feminina - mais facilmente assimilada à exclusividade sexual e ao envolvimento (ainda que mínimo) emocional. Se as mulheres permitem-se viver suas sexualidades de modo mais livre - e isso obviamente tem sua faceta positiva - por outro lado é preciso reconhecer que os estereótipos de gênero podem trazer

alguns produtos como um fator de liberdade e emancipação, e isso acontece também no mercado erótico, naquilo que Gregori (2016) chama de boutiques eróticas e sex shops. Com efeito, "o consumidor procura o sexo como afirmaçáo social, pessoal e afetiva. O poder econômico é representado pela posse de símbolos sexuais representados por marcas e categorias de produtos." (GREGORI, 2016, p. 95). 
consequências problemáticas no que diz respeito às mulheres que pretendem casar-se ou compartilhar suas vidas com alguém, notadamente em se tratando de relacionamentos heterossexuais, pois os homens infelizmente continuam classificando as mulheres em uma ordem hierárquica que as concebem como ideais para o casamento ou não, repristinando noçóes arcaicas sobre as quais discorreu-se na primeira seção deste texto.

Dessa discussáo, conclui-se que, no debate que envolve a sexualidade, seus limites e os direitos sexuais verifica-se, atualmente, um certo deslocamento no sentido de qualificar de modo distinto práticas sexuais que anteriormente eram menosprezadas ou negativamente valoradas, a exemplo do adultério, da masturbação, da pornografia ${ }^{19}$, da prostituição e da homossexualidade. Por outro lado, há uma conotação cada vez mais expressa de cunho condenatório no que diz respeito ao assédio sexual, ao estupro e à pedofilia, por exemplo. Tais mudanças de perspectiva criam novas ansiedades relacionadas ao que é possível enquadrar como um limite aceitável, criando uma espécie de esquizofrenia ou pânico sexual. Para o feminismo, a repercussão é particularmente complexa, já que vertentes mais radicais do movimento vêm concebendo a liberação sexual, nesses termos, como mera extensão dos privilégios masculinos (HEILBORN, 2006).

O importante de tudo isso é compreender que as práticas eróticas não convencionais podem ser concebidas como diferentes formas de expressão sexual, desde que em contextos da maturidade, respeito e consciência entre os envolvidos. É certo também que é tênue a linha que separa práticas consensuais das ditas perversóes, mas é fundamental questionar aqueles conceitos pré-estabelecidos, a fim de que seja possível conceber o erotismo não convencional como um direito à diferença também no cenário dos direitos sexuais (MARTINS; CECCARELLI, 2003).

Muitas outras temáticas poderiam ser abordadas quando se propóe uma discussão em torno dos temas e dos pactos que movimentam a cena dos direitos sexuais e a sua (não) regulação. Todavia, atendendo à necessidade de concisão, limitar-se-á a pesquisa aqui traçada aos temas ora apresentados, os quais certamente mais suscitam dúvidas e questionamentos do que esclarecimentos. O importante é que seja possível visualizar a (ou saber da) individualidade existente em cada ser, compreendendo e aceitando as diferenças como dimensões da inusitada e incomensurável pluralidade da experiência humana.

19 Apesar de persistir um discurso negativo a respeito, percebe-se que a pornografia tem sido utilizada recentemente no sentido de possibilitar a emancipação e o empoderamento femininos, o que fica muito evidente na obra da cineasta sueca Erika Lust. Preocupada com o impacto negativo do pornô tradicional na vida das pessoas (notadamente das mulheres), Erika dirige filmes pornográficos que objetivam romper com os estereótipos de gênero sustentados pela indústria tradicional. "Eu quero mostrar toda a paixão, intimidade, amor e luxúria no sexo, onde o ponto de vista feminino é vital, a estética é um prazer para todos os sentidos, e aqueles que buscam uma alternativa à pornografia convencional podem encontrar um lar", são as palavras que escancaram o site (erikalust.com) e em cujas nuanças se percebe um design sofisticado, sensual e feminilizado. 


\section{Consideraçóes finais}

É fato que o sexo se converteu em um centro ao redor do qual toda a tecnologia da vida humana se desenvolve. Parece, no entanto, haver uma tensão de fundo inconciliável entre a epistemologia contemporânea da sexualidade e os fundamentos da teoria e prática da lei e do Direito. Aquela é fluída, instável, plural, efêmera, imprevisível e, portanto, não pode ser perfeitamente apropriada. Esses, por outro lado, funcionam a partir do código bom-mau, certo-errado, lícito-ilícito. Dito de outro modo, as práticas sexuais e as identidades são concepçóes fluidas e instáveis, ao passo em que as definições normativas são engessadas, limitadas. Os consensos normativos, por mais progressistas e liberais que sejam, são contingentes e excludentes.

A partir das considerações feitas, conclui-se que uma premissa fundamental para conceber a sexualidade em termos mais libertários e emancipadores implica o reconhecimento de que as identidades e manifestaçóes sexuais sáo fluidas, instáveis e mutáveis, de modo que as definiçóes a seu respeito devem ser as mais abrangentes possíveis.

O modelo familiar heteronormativo persiste como regra no imaginário coletivo, mas a dinâmica social aponta para novas possibilidades que abarcam desde os relacionamentos homossexuais até as unióes poliafetivas. Sexo, gênero e sexualidade, nesse sentido, revelam-se como categorias maleáveis (pela cultura, pela religião, pela biologia) e fluídas, permeadas ora por conservadorismos, ora por ondas liberais. No que se refere às unióes homoafetivas, verifica-se um primeiro processo de descriminalização, passando pela legalização da união civil com posterior equiparação ao casamento heterossexual. Desnecessário dizer que a reivindicação política avançará, com os novos temas da gramática do erotismo não convencional, exigindo das ciências jurídicas um novo modo de pensar a partir de outras experiências sociais que se colocaráo na ordem do dia.

Evidencia-se que embora as identidades assumam especial relevância do ponto de vista do cotidiano, talvez seja mais interessante para o Direito (e possivelmente menos problemático) estabelecer direitos fundamentais de maneira desvinculada às identidades.

É que como um instituto que se estabelece a partir das relações com o seu oposto, incluir - na lógica jurídica - a partir da identificação, inevitavelmente acarretará exclusóes. É dizer, toda legislação que se propor a reconhecer explicitamente determinadas identidades está, em verdade, fadada ao fracasso, já que apenas está protegendo processos de identificação. É o caso das uniōes homoafetivas, pois na tentativa de proteger a mulher enquanto um sujeito vulnerável em termos de gênero, por melhor que fosse a intenção do legislador constituinte, outras inúmeras identidades tão vulneráveis quanto a própria mulher se percebeu sem proteção jurídica adequada. 
Então, até que ponto o sistema jurídico consegue universalizar o direito à identidade, especialmente no tocante à sexualidade? Este estudo defende que o Direito, por adotar determinadas generalizaçóes, seleciona certos traços de identificação, afastando outros (igualmente importantes). Talvez seja hora de restaurar, pelo menos do ponto de vista legislativo, uma humanidade comum do ser humano enquanto modelo universal de direitos humanos, o que não implica, necessariamente, adotar uma racionalidade jurídica estandartizadora e sectária. Somente assim será possível conceber um paradigma jurídico de justiça erótica, de libertaçáo sexual e diversidade familiar, reconhecendo que negar os direitos conjugais, parentais e sobretudo existenciais de pessoas LGBTI é a negação expressa de sua própria condição de seres humanos.

Dito de outro modo, em muitos casos há sequer regulação a ser feita, o que significa que nessa imensa gama de práticas eróticas não convencionas, a ausência de danos e o consentimento manifestado livremente são os únicos elementos a respeito dos quais o Direito talvez possa discorrer. Apropriar-se de todas nuanças da sexualidade exige uma articulação entre identidade, política, corpo e regime jurídico que foge em absoluto ao alcance das possibilidades discursivas das ciências jurídicas. De fato, aquilo que podemos conceber como uma justiça erótica- e aqui, reitera-se, envolvendo tão somente adultos sem vícios de consentimento - somente será possível se forem deixados de lado os diferentes signos e conteúdos que cada sujeito empresta à sua eroticidade e aos seus pactos.

\section{Referências}

AGUSTÍN, Laura. Sex at the margins: migration, labour markets and the rescue industry. Londres/Nova York, Zed Books, 2007.

ALMEIDA JÚNIOR, A.; COSTA JÚNIOR, J. B. de O. Lições de medicina legal. 15. ed. São Paulo: Companhia Editora Nacional, 1978.

ANDERSON, Elizabeth. Value in ethics and economics. London: Harvard University Press, 1993.

AQUARIUS. Direção: Kleber Mendonça Filho. Produção: Emilie Lesclaux, Saïd Ben Saïd e Michel Merkt. Brasil, 2016. 145 minutos.

BATAILLE, Georges. O erotismo. Tradução de Fernando Scheibe. Belo Horizonte: Autêntica Ed., 2014.

BEAUVOIR, Simone. O segundo sexo. Tradução de Sérgio Milliet. 2. ed. 2. v. Rio de Janeiro: Nova Fronteira, 2009. 
BORRILLO, Daniel. O sexo e o direito: a lógica binária dos gêneros e a matriz heterossexual da lei. Revista Meritum, Belo Horizonte, v. 5, n. 2, jul./dez. 2010. Disponível em: http://www.fumec.br/revistas/meritum/article/view/1092. Acesso em: 13 maio 2017. p. 289-321.

BORRILLO, Daniel. Uma perspectiva crítica das políticas sexuais e de gênero. Gênero, sexualidade e direitos humanos. Porto Alegre: maio de 2015. Disponível em: https://hal. archives-ouvertes.fr/hal-01240641/document. Acesso em: 15 maio 2017.

BRASIL. Decreto-Lei no 1.001, de 21 de outubro de 1969. Código Penal Militar. Disponível em: http://www.planalto.gov.br/ccivil_03/decreto-lei/Del1001Compilado. htm. Acesso em: 06 jun. 2019.

BRASIL. Decreto-Lei no 2.848, de 7 de dezembro de 1940. Código Penal. Brasília, 07 dez. 1940. Disponível em: http://www.planalto.gov.br/ccivil_03/decreto-lei/ del2848compilado.htm. Acesso em: 06 jun. 2019.

BRASIL. Supremo Tribunal Federal. Mandado de Injunção (MI) no 4.733. Relator: Ministro Edson Fachin, Brasília, Disponível em: http://portal.stf.jus.br/processos/ detalhe.asp?incidente=4239576. Acesso em: 06 jun. 2019.

BUTLER. Problemas de gênero: feminismo e subversão da identidade. Tradução de Renato Aguiar. 10. ed. Rio de Janeiro: Civilização Brasileira, 2016.

CASTRO GOMES, Carla de. Corpo e emoção no protesto feminista: a Marcha das Vadias do Rio de Janeiro. Sexualidad, Saludy Sociedad. Rio de Janeiro, n. 25, p. 231-255, abr. 2017. Disponível em: http://www.scielo.br/scielo.php?script=sci_ arttext\&pid=S1984-64872017000100231\&lng=en\&nrm=iso. Acesso em: 12 nov. 2017.

CORRÊA, Sonia. Cruzando a linha vermelha: questóes não resolvidas no debate sobre direitos sexuais. Horizontes Antropológicos. 2006, vol.12, n. 26, pp. 101-121. ISSN 0104-7183. Disponível em: http://www.scielo.br/scielo.php?script=sci_ issuetoc\&pid=0104-718320060002\&lng=pt\&nrm=iso. Acesso em: 03 nov. 2016.

DELEUZE, Gilles. Diferença e repetição. Rio de Janeiro: Graal, 1988.

DERRIDA, Jacques; ROUDINESCO, Elizabeth. De que amanhã: diálogo. Tradução de André Telles. Rio de Janeiro: Zahar Ed., 2004.

DIAZ-BENITEZ, María Elvira. Sexo com animais como prática extrema no pornô bizarro. Cadernos Pagu, Campinas, n. 38, p. 241-279, jun. 2012. Disponível em: http:// www.scielo.br/scielo.php?script=sci_arttext\&pid=S0104-83332012000100009\&lng=e n\&nrm=iso. Acesso em: 20 ago. 2017.

DUSSEL, Enrique. Politica de la liberación: historia mundial y crítica. Madrid: Trotta, 2007. 
FENICHEL, Otto. Teoria psicanalitica das neuroses. Rio de Janeiro: Ateneu, 1981.

FERRY, Luc. Famílias, amo vocês: política e vida privada na era da globalização.

Tradução de Jorge Bastos. Rio de Janeiro: Objetiva, 2008.

FOUCAULT, Michel. História da sexualidade I: a vontade de saber. 22. impr. Rio de Janeiro: Ed. Graal, 2012.

FOUCAULT, Michel. Microfisica do poder. 4. ed. Rio de Janeiro: Graal, 1984.

FOUCAULT, Michel. Os anormais: curso no Collège de France. São Paulo: Editora WMF Martins Fontes, 2014a.

FREUD, Sigmund. Obras completas, v. 6: três ensaios sobre a teoria da sexualidade, análise fragmentária de uma histeria ("O caso Dora") e outros textos (1901-1905). Tradução de Paulo César de Souza. São Paulo: Companhia das Letras, 2016.

GIDDENS, Anthony. A transformação da intimidade: sexualidade, amor e erotismo nas sociedades modernas. Tradução de Magda Lopes. São Paulo: Ed. UNESP, 1993.

GREGORI, Maria Filomena. Práticas eróticas e limites da sexualidade: contribuiçôes de estudos recentes. Cadernos Pagu, Campinas, n. 42, p. 47-74, jun. 2014. Disponível em: http://www.scielo.br/scielo.php?script=sci_arttext\&pid=S010483332014000100047\&lng=en\&nrm=iso. Acesso em: 20 ago. 2017.

GREGORI, Maria Filomena. Prazeres perigosos: erotismo, gênero e limites da sexualidade. São Paulo: Companhia das Letras, 2016.

HEILBORN, Maria Luiza. Entre as tramas da sexualidade brasileira. Revista Estudos Feministas, Florianópolis, v. 14, n. 1, p. 43-59, 2006. Disponível em: http://www.scielo. br/pdf/ref/v14n1/a04v14n1.pdf. Acesso em: 25 jun. 2017.

ILGA. Sexual orientation laws in the world - Overview. Maio 2017. Disponível em: http://ilga.org/downloads/2017/ILGA_WorldMap_ENGLISH_Overview_2017.pdf. Acesso em: 28 jan. 2018.

ILLOUZ, Eva. ¿Por qué duele el amor? Una explicación sociológica. Buenos Aires: Katz Ed., 2016.

ILLOUZ, Eva. Erotismo de autoayuda: cincuenta sombras de Grey y el nuevo orden romántico. Buenos Aires: Katz, 2014.

ILLOUZ, Eva. O amor nos tempos do capitalismo. Traduçáo de Vera Ribeiro. Rio de Janeiro: Zahar, 2011.

KARDINER, Abram. Lindividu dans as société. Paris: Gallimard, 1969.

LALLEMENT, Michel. História das ideias sociológicas. 3. ed. Petrópolis: Vozes, 2008. 
LARAIA, Roque de Barros. Cultura: um conceito antropológico. Rio de Janeiro: Jorge Zahar Editor, 2001.

LEITE, Gabriela. Filha, mãe, avó e puta: a história de uma mulher que decidiu ser prostituta. Rio de Janeiro: Objetiva, 2009.

LIMA, Agostinho J. de Souza. Tratado de medicina legal. 4. ed. Rio de Janeiro: Leite Ribeiro, 1924.

MARTINS, Maria Cristina; CECCARELLI, Paulo Roberto. Práticas sexuais ditas "desviantes": perversão ou direito à diferença? In: Revista Terapia Sexual, v. 6, n. 1, 2003. pp. 34-52. Disponível em: http://ceccarelli.psc.br/pt/?page_id=203. Acesso em: 26 ago. 2017.

MARX, Karl. A questão judaica. 2. ed. São Paulo: Moraes, 1991.

MCCLINTOCK, Anne. Maid to order: commercial S/M and gender power. In: GIBSON, Pamela; GIBSON, Roma (Orgs.). Dirty Looks. London: British Film Institute, 1994.

MCDOUGALL, Joyce. As múltiplas faces de Eros. São Paulo: Martins Fontes, 1997.

MEAD, Margaret. Moeurs et sexualité en Océanie: au coeur des sociétés traditionnelles des îles Samoa et de Nouvelle-Guinée. 1928-1935. Paris: Plon, 1963, pp. 251-252.

MISKOLCI, Richard. Desejos digitais: uma análise da busca por parceiros on-line. Belo Horizonte: Autêntica Ed., 2017.

NIETZSCHE, Friedrich. A gaia ciência. Tradução de Paulo César de Souza. São Paulo: Companhia das Letras, 2012.

NIETZSCHE, Friedrich. A vontade de poder. Tradução de Marcos Fernandes e Francisco Moraes. Rio de Janeiro: Contraponto, 2008.

NUSSBAUM, Martha C. Pela razão ou preconceito: ganhar dinheiro com o uso do corpo. Cadernos Themis Gênero e Direito. Ano 3, n. 3. Porto Alegre: Themis Assessoria Jurídica e Estudos de Gênero, 2002. p. 13-53.

OLIVAR, José Miguel Neto. Devir puta: políticas de prostituição nas experiências de quatro mulheres militantes. Rio de Janeiro: EdUERJ, 2013.

OLIVAR, José Miguel Neto. Prostituição feminina e direitos sexuais... diálogos possíveis? Sexualidad, Salud y Sociedad. Revista Latinoamericana, Norteamérica, 0, jul., p. 88-121, 2012. Disponível em: http://www.e-publicacoes.uerj.br/index.php/ SexualidadSaludySociedad/article/view/2681/2392. Acesso em: 13 ago. 2017.

PISCITELLI, Adriana. Apresentação: gênero no mercado do sexo. Cadernos Pagu, Campinas, n. 25, p. 7-23, dez. 2005. Disponível em: http://www.scielo.br/scielo. 
php?script=sci_arttext\&pid=S0104-83332005000200001\&lng=en\&nrm=iso. Acesso em: 17 ago. 2017.

QUINALHA, Renan. "Menino veste azul, menina veste rosa”: uma polêmica inútil? In: Cult, 04 jan. 2019. Disponível em: https://revistacult.uol.com.br/home/menino-vesteazul-menina-veste-rosa/. Acesso em: 05 jun. 2019.

RICHARDS, Jeffrey. Sexo, desvio e danação: as minorias na Idade Média. Tradução de Marco Antonio Esteves da Rocha e Renato Aguiar. Rio de Janeiro: Jorge Zahar, 1993.

RIOS, Roger Raupp. Notas para o desenvolvimento de um direito democrático da sexualidade. In: RIOS, Roger Raupp. Porto Alegre: Livraria do Advogado, 2007. p. 1338.

ROMI, Juan Carlos. Las Perturbaciones sexuales: críticas a su inclusión como trastornos mentales en el DSM IV TR. Psiquiatría Forense, Sexología y Praxis, año 15, v. 6, n. 1, marzo de 2008. Disponível em: http://www.medicinaforenseperu.org/media/ documentos/20100212164804.pdf. Acesso em: 6 jun. 2019.

ROUDINESCO, Elizabeth. A família em desordem. Rio de Janeiro: Jorge Zahar, 2003.

ROUDINESCO, Elizabeth. A parte obscura de nós mesmos: uma história dos perversos. Tradução de André Telles. Rio de Janeiro: Jorge Zahar Ed., 2008.

SANTOS, André Leonardo Copetti; LUCAS, Doglas Cesar. A (in)diferença no Direito. Porto Alegre: Livraria do Advogado, 2015.

STEARNS, Peter N. História da sexualidade. Tradução de Renato Marques. São Paulo: Contexto, 2010.

STOLLER, Robert J. Perversão: a forma erótica do ódio. Tradução de Maria Lúcia L. da Silva. São Paulo: Hedra, 2015.

STRECK, Lenio Luiz. Hermenêutica jurídica e $(m)$ crise: uma exploraçáo hermenêutica da construção do Direito. 11. ed. rev., atual. e ampl. Porto Alegre: Livraria do Advogado, 2014.

WARAT, Luis Alberto. A ciência jurídica e seus dois maridos. 2. ed. Santa Cruz do Sul: EDUNISC, 2000.

YALOM, Irvin D. O carrasco do amor e outras histórias sobre psicoterapia. Tradução de Maria Adriana Veríssimo Veronese. 2. ed. Rio de Janeiro: Harper Collins Brasil, 2016. 